\title{
Intellectual \\ Property Rights and \\ Global Capitalism
}




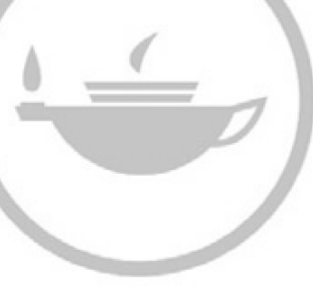

\section{Taylor \& Francis Taylor \& Francis Group}

http://taylorandfrancis.com 


\section{Intellectual}

Property Rights and Global Capitalism

The Political Economy of the TRIPS Agreement

Donald G. Richards 
First published 2004 by M.E. Sharpe

Published 2015 by Routledge

2 Park Square, Milton Park, Abingdon, Oxon OX14 4RN

711 Third Avenue, New York, NY 10017, USA

Routledge is an imprint of the Taylor \& Francis Group, an informa business

Copyright @ 2004 Taylor \& Francis. All rights reserved.

No part of this book may be reprinted or reproduced or utilised in any form or by any electronic, mechanical, or other means, now known or hereafter invented, including photocopying and recording, or in any information storage or retrieval system, without permission in writing from the publishers.

Notices

No responsibility is assumed by the publisher for any injury and/or damage to persons or property as a matter of products liability, negligence or otherwise, or from any use of operation of any methods, products, instructions or ideas contained in the material herein.

Practitioners and researchers must always rely on their own experience and knowledge in evaluating and using any information, methods, compounds, or experiments described herein. In using such information or methods they should be mindful of their own safety and the safety of others, including parties for whom they have a professional responsibility.

Product or corporate names may be trademarks or registered trademarks, and are used only for identification and explanation without intent to infringe.

\section{Library of Congress Cataloging-in-Publication Data}

Richards, Donald (Donald G.)

Intellectual property rights and global capitalism : the political economy of the TRIPS Agreement / Donald G. Richards.

p. $\mathrm{cm}$.

Includes bibliographical references and index.

ISBN 0-7656-1362-X (hardcover : alk. paper)

1. Intellectual property-Economic aspects. 2. Foreign trade regulation--Economic aspects. 3. Developing countries-Economic conditions. 4. Capitalism. I. Title.

K1401.R53 2004

$346.04^{\prime} 8-\mathrm{dc} 22$

ISBN 13: 9780765613622 (hbk) 
For

Jennifer, Emily, and Erin 


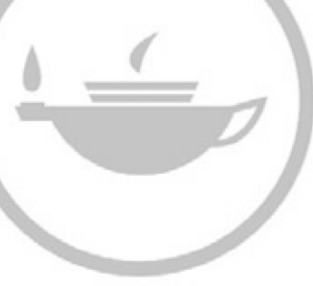

\section{Taylor \& Francis Taylor \& Francis Group}

http://taylorandfrancis.com 


\section{Contents}

Tables

viii

Acronyms

Acknowledgments

1. Introduction and Background

2. The Ideology of Intellectual Property

3. Intellectual Property and Positivist Economic Science

4. Capital, Class, and the State in the Global Economy

5. The Political Economy of TRIPS

6. TRIPS and the Global Pharmaceutical Industry

7. Intellectual Property Rights and the Agricultural Biotechnology Revolution

8. Counterhegemony and the Future of TRIPS

Notes

References

Index

About the Author 


\section{Tables}

3.1 IPR Index Scores

65

3.2 Patent Rights and DFI

70

6.1 R\&D Expenditure by Geographic Area for U.S.-Based PhRMA Member Companies, 2000

6.2 Domestic R\&D of PhRMA Companies by Product Class, 2000

7.1 Global Area Dedicated to Genetically Modified Crops, 1996-2002 


\section{Acronyms}

$\begin{array}{ll}\text { AA } & \text { Agreement on Agriculture } \\ \text { ACTPN } & \text { Advisory Committee on Trade Policy and Negotiations } \\ \text { AIDS } & \text { acquired immunodeficiency syndrome } \\ \text { AMS } & \text { aggregate measure of support } \\ \text { ATC } & \text { Agreement on Textiles and Clothing } \\ \text { BR } & \text { biotechnology revolution } \\ \text { CAP } & \text { Common Agricultural Policy } \\ \text { CBD } & \text { Convention on Biological Diversity } \\ \text { CDC } & \text { Centers for Disease Control } \\ \text { CGIAR } & \text { Consultative Group on International Agricultural Research } \\ \text { DFI } & \text { direct foreign investment } \\ \text { DSP } & \text { disputes settlements procedures } \\ \text { EU } & \text { European Union } \\ \text { FAO } & \text { Food and Agriculture Organization } \\ \text { GATS } & \text { General Agreement on Trade in Services } \\ \text { GATT } & \text { General Agreement on Tariffs and Trade } \\ \text { GMO } & \text { genetically modified organism } \\ \text { GP } & \text { Ginarte and Parks } \\ \text { GR } & \text { green revolution } \\ \text { GSP } & \text { Generalized System of Preferences } \\ \text { HDI } & \text { Human Development Index } \\ \text { HIV } & \text { human immunodeficiency virus } \\ \text { HYV } & \text { high-yielding variety } \\ \text { IARC } & \text { international agricultural research center } \\ \text { IBPGR } & \text { International Board for Plant Genetic Resources } \\ \text { IIPA } & \text { International Intellectual Property Alliance } \\ \text { ILO } & \text { International Labor Organization } \\ \text { IMF } & \text { International Monetary Fund } \\ \text { IOC } & \text { internationalization of capital } \\ \text { IP } & \text { intellectual property } \\ \text { IPC } & \text { Intellectual Property Committee } \\ \text { IPE } & \text { international political economy } \\ \text { IPL } & \text { Industrial Property Law } \\ & \end{array}$




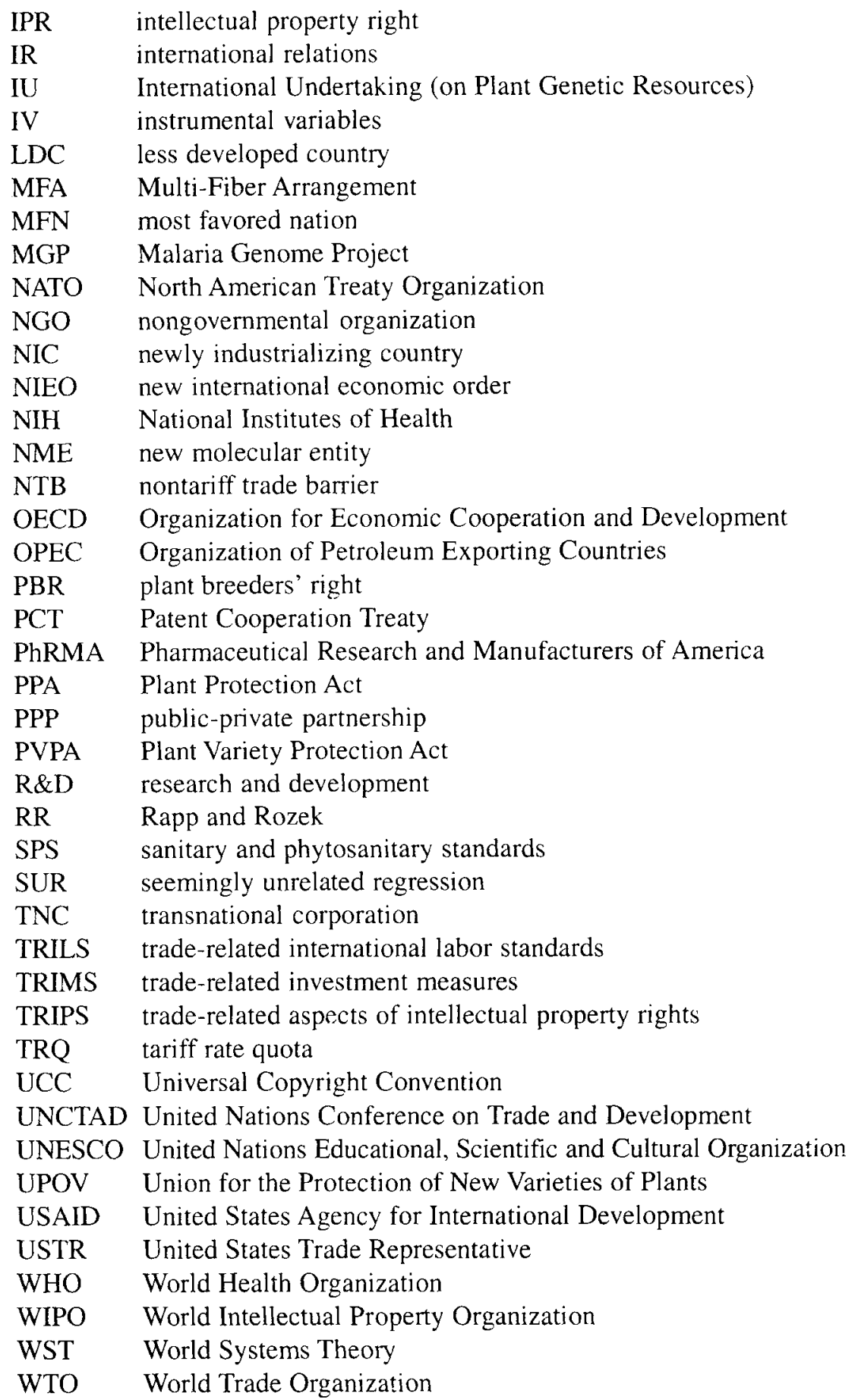




\section{Acknowledgments}

Several people commented on various versions of the chapters contained in this book. Many of their comments and suggestions have caused me to alter or elaborate the arguments made here in one way or another. None of these individuals, however, bears any responsibility for the remaining shortcomings of the work, as these are entirely my own. In particular, I would like to thank Paul Burkett and Christopher May for many valuable insights and suggestions for improvements. Anonymous referees at the Review of Social Economics and Review of International Political Economy also made important contributions to improving parts of the argument. A shorter version of Chapter 2 appears in Review of Social Economics, whose publisher, Routledge, I wish to thank for permission to reprint. A debt is also owed to the following organizations for permission to reprint data tables: Union of Concerned Scientists, Institute of International Economics, Pharmaceutical Research and Manufacturers of America, and International Service for the Acquisition of Agri-biotech Applications. Thanks to my colleagues and students at Indiana State University, who continue to be a source of professional inspiration and intellectual stimulation. Finally, thanks to the editors at M.E. Sharpe and especially to Laurie Lieb and Henrietta Toth who did such a thorough and professional job in copyediting the manuscript. 


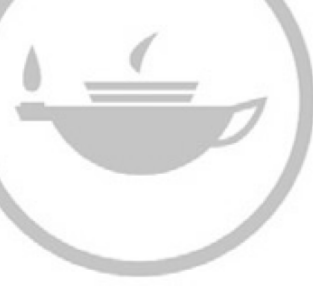

\section{Taylor \& Francis Taylor \& Francis Group}

http://taylorandfrancis.com 


\section{Intellectual \\ Property Rights and Global Capitalism}




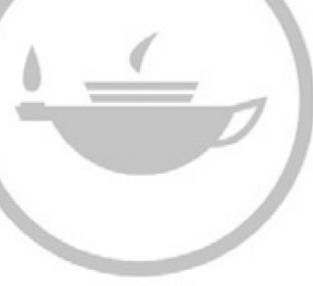

\section{Taylor \& Francis Taylor \& Francis Group}

http://taylorandfrancis.com 


\section{1 \\ Introduction and Background}

My purpose in writing this book is to examine of the origins and impact of the agreement on trade-related aspects of intellectual property rights (TRIPS) negotiated during the Uruguay Round of talks of the General Agreement on Tariffs and Trade (GATT). The principle theme of the book is that the TRIPS agreement is not in the best social welfare interest of the poor countries and that its effective imposition on them by the rich countries has far more to do with the exercise of real political and economic power than it does with the positive economic benefits the agreement's supporters claim it can deliver. To support this assertion, I provide a critical examination of the theoretical literature and empirical evidence as they pertain to the impact of intellectual property rights (IPRs) on such important economic variables as export performance, foreign investment, and economic growth. This examination demonstrates the overall weakness of the positivist economic case in favor of a strong international IPR regime, at least as it applies to the poor countries. ${ }^{1}$

The book then proceeds to provide a political and economic analysis that explains why the poor countries acceded to the TRIPS agreement notwithstanding the lack of positivist economic evidence in favor of its benefits. The analysis here is driven by a theory of the state in the global system which is itself the product of a method I choose to describe as "critical eclecticism." By this term I mean that the approach to state theory I adopt is inspired by several well-established traditions in radical political economy and international relations theory that speak to, or carry implications for, the relations between the state and civil society. The constituent approaches are (1) world systems theory, (2) Gramscian hegemony, and (3) internationalization of capital. My method is critical in two senses of the word. First, it is critical in the same sense that these constituent traditions are critical. That is, it calls into question the dominant institutional infrastructure by which the global system is administered, and it advocates fundamental reforms to benefit the world's marginalized majority. Second, it is critical in the sense that it does not attempt to include or reconcile all aspects of each of the three component radical research traditions. It recognizes that each tradition has differences of emphasis and strength and draws on these as they advance the analysis at 
hand. I do argue that the three approaches are in fact mutually consistent at a fundamental level. I do not pretend to settle old debates among and between the schools that have often taken on a polemical character in the past.

Having advanced the general political and economic analysis of the TRIPS agreement, the book then proceeds to illustrate with a pair of case studies of two important industries where the struggle over IP is especially strongly waged. These are the pharmaceutical and agricultural biotechnology sectors. In each of these cases, an attempt is made to specify the IPR issues and demonstrate how the TRIPS agreement operates to define and extend capitalist social relations of production on a global scale. It does this in part, I argue, by operating as a mechanism of (Gramscian) consensual hegemony. At the same time, it is recognized that ideological struggle is not strictly determined and that the door is open for counterhegemonic efforts. These cases reveal the conditions under which counterhegemony is more likely to succeed.

TRIPS is a relatively recent phenomenon and the literature devoted to its analysis is still relatively undeveloped. Most of the work that has been done in this area by scholars from the developed countries tends to promote the benefits of a strong international IPR regime. I know of no work in this area that approaches the general case of the TRIPS agreement from a radical perspective of political and economic international relations of the type I develop here. Later in this chapter I review some of the recent related literature and show how my own contribution extends, improves on, and/or corrects this work.

\section{The TRIPS Agreement in Basic Outline}

The TRIPS agreement is not a sui generis system for the international protection of intellectual property rights. It traces its historical and juridical roots to several earlier international agreements, two of which date back to the nineteenth century. The Paris Convention for the Protection of Industrial Property of 1883 and the Berne Convention for the Protection of Literary and Artistic Works of 1886 were precursors of the TRIPS agreement. The Paris agreement required signatory nations to provide national treatment for foreign innovations in the areas of patents, trademarks, industrial designs, appellations of origin, and utility models, while the Berne Convention did the same for copyrights. National treatment, however, does not require nations to provide any particular standard of protection. It merely requires that whatever level is provided to domestic works also be provided to foreign works. Essentially, then, the Paris and Berne conventions amount to nondiscrimination agreements in the area of IPRs rather than agreements that establish 
minimum standards. Nonetheless, the two conventions were not universally embraced: some countries chose not to become signatories in the belief that the agreements represented constraints on the countries' abilities to reap the benefits of technological transfer and development. ${ }^{2}$

In 1893 the Paris and Berne conventions were merged into a single secretariat to be administered by the World Intellectual Property Organization (WIPO) (Ryan 1998, p. 126). WIPO subsequently became a part of the United Nations system in 1974. Its mission is to help nations develop multilateral norms governing IP, help nations develop national legislation, and facilitate the negotiation of international treaties. As Ryan notes, however, WIPO operated under the same constraints as its predecessor agreements. That is, while some members of WIPO attempted to press for effective minimum standards for IP protection, there was within the organization considerable resistance to these attempts as well. Neither was WIPO endowed with an effective mechanism to enable it to enforce what minimum provisions its membership was able to agree to. The inadequacies of WIPO can fairly be identified as the inspiration motivating the movement to establish the TRIPS agreement as part of the multilateral trade negotiating system and institutional framework. The demonstrated effectiveness of the latter in liberalizing trade, its effectiveness in enforcing its various provisions, and its ability to settle disputes, or at least limit their negative fallout, made the GATT/World Trade Organization (WTO) an obvious choice for those who advocated a strengthening of the international IPR regime.

The basic function of the TRIPS agreement is to establish and enforce minimum international standards for the protection of intellectual property. As such, it does not literally seek to bring about the international harmonization of IPRs inasmuch as nations are free to adopt national IPR regimes that provide more extensive protection than that called for by the agreement. It does require that nations adhere to the main provisions of the Paris and Berne conventions while calling for nothing that derogates nations' obligations to one another under those agreements. Thus, for example, the basic principles of national treatment and most favored nation are strongly enshrined in the TRIPS agreement. ${ }^{3}$

Beyond this, as noted, the TRIPS agreement stipulates that certain minimum requirements for IP protection be met by the WTO nations. In the area of copyright, works are afforded a period of exclusionary protection equal to fifty years after the life of the author, and copyright protection is extended beyond printed matter to include sound and video recordings (Articles 12 and 14). Copyright protection is also provided to computer software programs as well as to compilations of data that represent a necessary degree of intellectual creativity. ${ }^{4}$ Minimum patent protection is established at twenty 
years and is extended by the prohibition of patent discrimination based on the place of invention, field of technology, or whether products are imported or locally produced (Article 27.1). Industrial designs are given similar protection for periods of at least ten years (Article 26.1). Article 18 allows for the registration of trademarks for periods of seven years that are indefinitely renewable, while Article 16 grants exclusive right of use of a registered trademark. Geographical indications are protected by Articles 22 and 23.

There are also some especially notable exceptions to the protections offered by the TRIPS agreement. Where patents are concerned, exceptions apply to living organisms developed by traditional methods. Compulsory licensing of patented products or processes is not allowed except in cases of national emergency. Transitional arrangements are allowed to enable poorer countries to update their legislation and establish the necessary administrative machinery to apply and enforce the law. Five years' grace is granted to less developed and transition countries with an additional five years for the poorest of these. All countries are expected to be compliant by 2005 .

\section{Recent Literature}

There have been a number of recent book-length publications (monographs and collected editions) devoted to the internationalization of intellectual property rights. In this brief review, I shall call attention to the strengths and weaknesses of a representative sample of these works in a manner that I hope makes clear the need for a political economic analysis of the type that I propose of the prevailing IPR regime. Some of the recent works are supportive of the prevailing IPR system, albeit with qualifications, while others are highly critical. Some of the recent scholarship may be considered, at least as I understand the concept, political economic in character while other works focus on the sociological, philosophical, or juridical aspects of IPRs. In drawing attention to these distinctions, I do not wish to denigrate the valuable contributions made by authors who write from a disciplinary emphasis that differs from my own. I wish only to convince the reader that a space exists that my own contribution seeks to fill. It will also be clear that I disagree with several of the general perspectives as well as the particular interpretations of the salient issues offered by the authors I review. This should come as no surprise to those even distantly familiar with the nature of intellectual property discussions.

The negotiations leading up to the establishment of the TRIPS agreement were extremely contentious. Leading the effort to establish the TRIPS were the United States, several European countries, and Japan. In these efforts, the U.S.-based pharmaceutical, telecommunications, and computer companies 
were especially prominent. Opposing the agreement were many middle and less developed countries, particularly India and Brazil, which seek to nurture incipient knowledge-intensive industries of their own. Predictably, the scholarly literature is also represented by voices that stand in support of the agreement, however qualified in some instances, and those that are opposed to it. I shall state at the outset my own view that the TRIPS agreement is not in the best interests of the poor countries of the world. More accurately, I do not believe it to be in the best material interests of the poor majorities who live and work in these countries. Neither is it clear that the agreement operates in the best interests of workers and consumers in general. A major task of this book is to explicate the reasons for such skepticism. A second major task is to provide an ex post facto explanation for the accession to the agreement by those very same poor countries. This explanation, I argue, must properly be conducted in political economic terms-a type of analysis I shall define in due course. Before delving into these and other related questions, however, a consideration of the relevant academic context is in order.

\section{Mainstream Economics Justifications of the TRIPS Agreement}

Standard economics justifications for intellectual property rights typically commence by recognizing that IPRs entail an inherent contradiction. On the one hand, welfare is maximized in a competitive economy by the free and complete availability of information. On the other hand, the production of knowledge and knowledge-intensive goods requires, as does any production in a market-based economy, incentives. Such incentives will be lacking in a regime that does not provide some restrictions on the access to information. This contradiction has led many economists to pose the problem in terms of "optimal" IPRs. Primo Braga (1990), in an early survey of the literature cites seminal contributions by Arrow (1962), Nordhaus (1969), and Scherer (1972) in his discussion of the optimal patent length, for example. Primo Braga recognizes that more recent theoretical developments, involving such dynamic considerations as the cost of patent races and the pace and reach of knowledge diffusion, call into question these early results. His general conclusion, however, is that there is a greater danger of insufficient investment in research and development $(R \& D)$ in developing countries rather than overinvestment.

In a more recent World Bank discussion paper, Primo Braga and coauthors Fink and Paz Sepulveda (2000) provide an updated survey of the economic impact of IPRs in the post-TRIPS environment. These writers once again note the welfare ambiguity of IPRs, paying particular attention to the questions of knowledge production and diffusion. They make the argument 
that while the short-term static impact of a strong IPR regime may well involve a welfare loss, owing to the exercise of monopoly power on the part of sellers of knowledge-based commodities and production processes, the longterm effects may be beneficial given the presence of additional, largely institutional, conditions. They note in particular the need for an effective competition poilcy that operates to ensure that the benefits of increased R\&D expected to follow from a stronger regime are widely spread. The development of the "human resource base" of the poorer countries is seen as necessary to increasing these benefits, as are greater macroeconomic stability and more open trade and investment regimes (p. 48). Even more fundamental for Braga, Fink, and Paz Sepulveda is the necessity of promoting a pro-IPR consensus among the broad swath of national stakeholders. They write:

\begin{abstract}
A first step for a developing country reforming its IPR regime should be to support initiatives that promote consensus. It is important to bring together all affected parties-local "pirates," research-based companies, universities, consumer groups, government agencies, industrial property offices, IPRs lawyers, and others-to discuss what IPRs "do" and "don't do," while attempting to evaluate the economic impact of IPRs reforms. Such an exercise can provide useful input for the formulation of new laws and help in identifying adversely affected groups and in the design of appropriate compensatory mechanisms. (p. 47)
\end{abstract}

This particular quotation raises a number of interesting issues. The first is the implicit admission that a fundamental task faced by proponents of a stronger IPR regime such as that embodied by the TRIPS agreement is to create a propitious ideological climate as a precondition for the success of such a regime. Apparently for these World Bank economists, the success of the TRIPS is primarily a problem of winning the confidence of those for whom the agreement can be expected to have potentially profound material consequences, even "local 'pirates." What is especially peculiar about this advice is that it comes on the heels of the admission by the authors that the available theoretical and empirical evidence is unable to demonstrate conclusively the alleged benefits of the enhanced regime. The authors give not a moment's consideration to the possibility that strengthening the IPR regime might be the wrong thing to do for a poor country.

Second, the authors make reference to "compensatory mechanisms" designed to reduce the burden of a stronger regime on those who are adversely affected. They refer in this case to the use of such options as parallel imports, compulsory licenses, and price controls as tools to be used to alter the distributional impacts of stricter control over intellectual property. These tools 
will be discussed in later chapters. The important questions to raise here are ones that the authors ignore altogether: What are the political economic conditions required for a country to successfully employ such measures and under what conditions will these measures be adequate to the country's developmental and distributional goals? Just as the establishment of the TRIPS agreement represented a struggle between contending international as well as intranational interests, the continuing application and interpretation of the agreement can be expected to be no less contentious. The authors' emphasis on consensus thus appears naive at best and disingenuous at worst.

Another recent work that takes an essentially positive view of the TRIPS agreement is Keith Maskus's Intellectual Property Rights in the Global Economy (2000). Like the other authors already cited, Maskus notes that IPRs have basically contradictory effects on (at least) short-term welfare. He argues that the theoretical prediction of the outcome of a strengthening of the IPR regime depends on the particular assumptions invoked. In his review of the available empirical evidence, including his own work, however, Maskus finds much to recommend the agreement and argues that its long-term net benefits are likely to outweigh its short-term costs. In particular, Maskus is optimistic about the agreement's potential to promote for the poorer countries higher levels of international trade and investment, foreign direct investment, and economic growth, each of which he believes is critical for promoting economic development. Once again, Maskus's optimism is contingent on the willingness and ability of the developing country to adopt a wide range of additional market reforms. He notes especially the importance of policies to bring greater flexibility to the labor market, to promote and regulate industrial competition, and to promote free trade. Many of these policy suggestions will be recognizable to anyone familiar with the so-called Washington consensus of the 1990s.

Given the similarities between Maskus's analysis and that of the authors discussed earlier, it should not come as a surprise to find that the former suffers from substantially the same shortcomings as the latter. Most prominently, Maskus, writing from a purely economic perspective, fails to give due recognition to the play of political forces and events. He pays little attention, for example, to the global political context in which the Uruguay Round of the GATT was conducted. While he recognizes in passing that the poorer nations faced considerable political pressure to assent to the TRIPS agreement, he does not examine the class-based origins or consequences of that pressure.

Mainstream economists frequently justify their choice to minimize or marginalize political considerations in their analyses by suggesting that such considerations are outside of their disciplinary purview and more properly 
require the attention of political scientists and/or international relations specialists. I would argue, however, that the tendency to consider apparently pure economic categories and evidence in isolation often results in a misinterpretation of that evidence. Take, for example, Maskus's data that show a correlation between strength of IPR regime and trade openness. Maskus interprets this correlation as a limited proof that a successful IPR regime must be accompanied by a liberal trading regime. But another interpretation is possible. Dependency theory might argue that strong IPR regimes together with a high degree of trade openness are typical of small nations and reflect dependency on external economic relationships and vulnerability to political pressure emanating from the more powerful countries. It is well known, for example, that certain former colonies of the nineteenth-century European powers adopted in wholesale fashion the strong IPR regimes of their colonizers. These former colonies also remain highly dependent on international trade, often with these same developed countries. Lacking a broader analytical framework, Maskus does not consider such a possibility.

\section{The TRIPS Agreement and International Law}

Standard economic interpretations of the TRIPS agreement, such as those discussed above, note the theoretical ambiguity of its likely impacts on the poorer countries yet still generally come down in favor of the agreement. The willingness to endorse the agreement may be driven by a belief in its historical inevitability and fueled by the expanding sense of market triumphalism that characterized the close of the Uruguay Round. This same attitude of final victory, in fact, resides at the heart of the Washington consensus and defines the aggressive neoliberalism of the 1990s typical of NorthSouth economic relations. ${ }^{5}$

The suggestion that the TRIPS agreement is now an unavoidable part of the international political economic superstructure seems to be at the heart of Carlos M. Correa's recent analysis in his Intellectual Property Rights, the WTO and Developing Countries (2000). Correa is an Argentine lawyer who considers the likely impact of the agreement on the southern nations that remain largely technologically and economically dependent on the North. He regards the agreement as a form of "technological protectionism" imposed by the United States with the aim of consolidating an international division of labor under which northern countries generate innovations and southern countries constitute the market for the resulting products and services (p. 5). As I shall argue in later chapters, in my estimation this is not far off from an accurate description of the agreement's effective motivation. Correa goes on to discuss rather convincingly the limited potential impact of 
the agreement in terms of its alleged long-term benefits. He suggests, for example, that DFI flows are not likely to be an important benefit inasmuch as IPRs are but one, and not the most important, determinant of these flows. Also, once IPRs reach a certain level of harmonization among the southern economies, they cease being a basis of differentiation between them for potential foreign investors and are, therefore, less relevant to DFI decisions (p. 30). Neither does Correa consider technology transfer from North to South as a necessary outcome of the TRIPS agreement. While the TRIPS may create the conditions for such a transfer, it may also operate to impair the ability of the southern economies to negotiate favorable terms.

Given Correa's skepticism regarding the motivation and likely consequences of the agreement, one might expect him to advocate its outright renunciation by the South. Rather than choose this course, Correa instead suggests that the poorer countries seek ways to adopt the agreement in a fashion that will yield them benefits. He asserts, "Despite the origins and main forces behind the TRIPS Agreement ... this Agreement still contains elements that, duly applied, may permit a certain balance in its implementation" (p. 6). The main body of Correa's book then is devoted to a legal parsing of the agreement's sections and subsections in a search for language that will enable an interpretation of the TRIPS useful to southern interests. Correa supplements his legal analysis with supporting case law citations on relevant IPR disputes that judicial authorities, including those that adjudicate WTO dispute settlements procedures (DSP) hearings, presumably would find persuasive. Thus, Correa maintains that Articles 7 and 8 permit member countries to take into account their own public interests in devising and implementing IPR law. In the area of patent law, less developed countries are free to define the concept of "invention" through their own national legislation or through administrative and judicial practice. There is no obligation under the TRIPS agreement to adhere to a unique concept of "invention" nor to adhere to a definition inspired by the expansive approach that exists in a developed country such as the United States (p. 51). This flexibility would be especially relevant in devising IPR policies in evolving and incompletely settled areas of IP, such as living organisms and computer software.

Correa notes that plant varieties may be protected by a less demanding sui generis approach to IPRs that permit farmers and researchers greater rights than would a patent system of protection. More generally, he argues that less developed countries (LDCs) may choose interpretations of the TRIPS agreement as it bears on plant genetic resources consistent with recently struck international agreements supported by the United Nations, such as the International Undertaking (IU) and the Convention on Biological Diversity (CBD), that seek to guarantee access to these materials. He also argues that the 
TRIPS agreement provides latitude with respect to the permissibility of parallel imports, compulsory licenses, and exclusions to IPRs based on a variety of national concerns considered to be of overriding importance-for example, public order or morality. To his credit, Correa does a much better job than Primo Braga, Fink, and Sepulveda in setting out the conditions under which such "compensatory mechanisms" might be applicable. Moreover, in general, he provides prospective opponents of the TRIPS with useful legal advice and guidelines for challenging the agreement on its own terms and in its own language. Ultimately, however, Correa's approach confronts several important limitations in both its analytical reach and its practical, political usefulness.

The most important constraint faced by those who would adopt Correa's legalistic approach is that although the agreement is worded in a manner that allows a variety of competing and conflicting interpretations of many important issues, as a practical matter, such conflicts will be resolved within the WTO's disputes settlements procedures (DSP). Even nonlawyers know that judicial reviews are hardly ever simply a matter of equally capable and wellendowed parties submitting their claims to otherwise disinterested judges for dispassionate consideration and resolution. The settlement of conflicts in the real world depends on the technical expertise and other resources that the contending parties can bring to bear in presenting their respective cases. As Correa is well aware, however, one of the many inequalities that separate the North and South resides precisely in their respective capabilities to marshal legal, technical, and administrative resources in defense of their interests in national and international forums.

Even on those occasions when poor countries do manage to win a favorable ruling in the WTO, it is an open question as to how effective or binding the judgment will be on the behavior of the richer country or corporate producers it represents. The GATT/WTO DSP operates by permitting compensatory retaliation toward countries that are found in violation of its provisions. Large developed countries can much more easily absorb such measures than can smaller, less developed ones. This has been historically true of normal trade disputes and we should expect it to be no less true of disputes involving IPRs. A country like the United States can be expected, then, to ignore DSP judgments rendered against it when they are not very costly and yet still take advantage of the mechanism to press its own complaints. Neither can we expect the United States to abandon its tendency to resort to unilateral pressures when the WTO does not work as efficaciously as it would like. Correa himself notes that the United States has recently imposed unilateral punishments against Argentina for alleged IPR violations although such unilateral actions stand in contradiction to the TRIPS agreement (p. 9). He also notes that the United States has aggressively employed other bilateral pressures to 
convince other Latin American and Caribbean nations to make extra TRIPS concessions (p. 110).

Finally, a limiting feature of Correa's legal approach is that it envisions nation-states acting on behalf of an imagined national interest. This is entirely understandable insofar as the TRIPS is in fact an agreement struck by nation-states. But it can hardly be realistically assumed that nations are homogeneous entities whose interests on IPRs and other matters can be univocally expressed. The TRIPS agreement, however interpreted, provides no mechanism or agency for the expression of nonofficial perspectives. Even when these perspectives are expressed via the agency of nongovernmental organizations (NGOs), their impact on TRIPS deliberations must necessarily pass through the filter of the state. It is a shortcoming of Correa's book that it provides no discussion of how state institutions and policies mediate between domestic groups and classes and their international counterparts in the context of the IPR debate. As I shall demonstrate, this shortcoming is shared by a substantial portion of the recent literature in this area.

\section{The TRIPS and International Capital}

Duncan Matthews's Globalising Intellectual Property Rights: The TRIPS Agreement (2002) is an authentically political economy treatment of the TRIPS agreement. What makes it so is the author's concern to detail the origins of the agreement as arising from the pressure exerted on policy makers by corporate interests to include the issue of IPRs on the negotiating agenda of the GATT Uruguay Round. Moreover, unlike some previous studies (i.e., Ryan 1998), Matthews demonstrates that these interests were not exclusively U.S.based, but instead included well-organized industrial groups in Europe and Japan. He argues in fact that had the Europeans and Japanese corporations not lobbied heavily in favor of including IPRs in the negotiations, the TRIPS agreement would never have been realized. The difference between U.S., on the one hand, and European and Japanese corporate involvement, on the other, in promoting the agreement, according to Matthews, was more a matter of lobbying style than it was commitment to the objective of strengthening the global IPR regime. Whereas U.S. business interests were able to operate in a very direct way to influence policy making by the United States Trade Representative (USTR), European- and Japanese-based companies needed to negotiate a more complicated and multilayered bureaucracy to influence policy. In the case of Europe, the problem of arriving at a consensus strategy for including IPRs in the negotiations was made more complicated by the emergence of the European Union.

Matthews also provides a much needed corrective to the tendency to 
view corporate, capitalist competitors as representing essentially national actors engaged in a global, competitive arena. He stresses instead the multinational character of the enterprises most likely to benefit from a strengthened global IPR regime. The role played by the global pharmaceutical industry is particularly salient in this regard. It is this same global, capitalist alliance that has also assumed major responsibility for seeing that the agreement is enforced. Matthews shows that the institutional mechanisms for the enforcement of the TRIPS, the WTO and WIPO, lack the oversight capabilities necessary for monitoring member-country compliance to its provisions. This function then is effectively relegated to private sector concerns who file complaints with the official regulatory bodies when they believe a violation has occurred. While the corporations themselves cannot play the role of plaintiff in WTO mediated disputes, they can, in Matthews's words, act as "the eyes and ears" of the developed country members in the disputes settlements procedures and in formulating legislation and administrative procedures (p. 4).

The object of this regulatory activity is, of course, primarily the poorer, less developed countries. Matthews does a good job of describing the potential costs and benefits of the agreement and their likely uneven incidence on the populations of the LDCs. He recognizes that the TRIPS agreement is bound to generate sympathizers among those groups that are able by virtue of training and connections to forge productive connections as input providers to the large transnational corporations who are the prime movers behind the agreement. These winners from the "talented class" will not be required to emigrate in order to advance their careers. Overall, however, according to the author, the results of the agreement will be to exacerbate the economic dependence of the poor countries on the developed world, which owns and controls the large share of the world's patents.

The question of effective enforcement of the TRIPS agreement raises for Matthews interesting questions about its long-term viability. ${ }^{6}$ In particular, he is concerned about the ultimate cohesiveness of the international capitalist alliance required for its functioning. This cohesiveness is threatened by the fact that nation-states typically pursue multifaceted foreign policies that inevitably bring them into conflict. While these developed nation-states may be able to form a temporary alliance to bring into existence a regulatory instrument that addresses a mutually felt need and general purpose, the actual functioning of the regime may well bring them into conflict with one another as well as with the LDCs. Moreover, national policies must address themselves to a wide range of national and international concerns-for example, international security or human rights - that in some circumstances dominate and conflict with those associated with IPRs and their administra- 
tion. There can be no presumption that the developed nation-states will achieve the same unanimity of outlook in these other areas that they have in the area of IPRs.

While these concerns of Matthews are logical, I do not agree that they constitute realistic obstacles to the future functioning of the TRIPS agreement. Moreover, I believe that Matthews's overestimation of their severity derives from the lack in his analysis of a sufficiently articulated theory of the state in the global economy. Matthews seems at times to operate on the basis of an implicit instrumentalist theory of state power wherein corporate actors are able to manipulate, directly or indirectly via access to key officials, the policy-making apparatus. ${ }^{7}$ While there is at times some truth to this perspective, it fails to account for the ability of the state at other times to resist or ignore particular corporate interests in order to attend to the general conditions required by capitalism for its expansion and reproduction on a global scale. The TRIPS agreement is precisely a part of this sort of general condition, which in recent decades has been identified as global neoliberalism. Neoliberal reform should not be oversimplified as implying the wholesale retreat of the state. It should be understood rather as constituting the sorts of structural changes in the global economic system that provide the best conditions for general capitalist reproduction. Clearly, this commitment by the state may conflict at times with the demands of particular segments of capital, including those relating to intellectual property. It should not come as a surprise, then, when particular IPRs are not given priority of treatment by the state.

A second criticism to make of Matthews's analysis concerns his treatment of class relations, which results in some inconsistencies and confusion. At times, Matthews makes clear that the TRIPS agreement is the result of the lobbying efforts of a transnational capitalist class. At other times, he writes as if policy outcomes, including those related to the interpretation and enforcement of IPRs, were strictly a matter of contending struggles between domestic class fractions. Moreover, he seems to regard differences in national policy agendas as a potential deterrent to the long-term success of the agreement. I believe that a less contradictory interpretation of the intraclass struggle over the TRIPS has more to do with the distinction that separates competitive from monopoly capital than it does with the national versus transnational origins of capital. The IPR debate is mostly a matter of the desire of monopoly capital to capture the firm-specific rents associated with knowledge-based outputs and processes. Certainly there are competitive firms as well as other domestic class fractions that will seek to challenge the terms and conditions under which commodified knowledge is traded in the marketplace. At times, this challenge is bound to be presented in 
thoroughly nationalistic discursive forms and cultural appeals. Those who wish to contest the hegemony exercised by noncompetitive transnational firms, however, would do well to keep in mind that the desire of these firms for profit provides a better guide to their behavior than their imagined nationalistic allegiances.

\section{Ideology and Intellectual Property Rights}

In contrast to neorealist interpretations of IPR policy such as that provided by Matthews, it is interesting to consider the views of others who see the issue in terms of ideology. Susan Sell, for example, in her Power and Ideas: North-South Politics of Intellectual Property and Antitrust (1998), places ideology at the center of an analytical approach she describes as "interpretivist neoliberal theory." Interpretivism, according to Sell, emphasizes "the intersubjective dimensions of international politics and treats interests as endogenous" (pp. 11-12). It privileges the force of ideas as compared to the materialism Sell associates with the more established analytical traditions that dominate international relations theory (p. 22). Individual nation-states, according to the author, are "unit-level learners and actors" who define and redefine a negotiating agenda in the pursuit of national self-interest. She then describes the rise and decline of the negotiating positions of southern states relative to northern states in such areas as restrictive business practices, technology transfer, antitrust, and IPRs, paying particular attention to the post1970 period. Sell asserts that while northern states have managed to win the hearts and minds of southern states in some of these areas-for example, antitrust, they must still resort to coercion to enforce IPRs.

Sell is optimistic, however, that southern unit-level actors (i.e., national governments) possess the capacity to learn from experiences, consider new ideas, and develop new negotiating positions. The ideological shift necessary for the success of the TRIPS agreement may be currently under way as nascent indigenous capitalist groups with an interest in strengthening local IPR regimes begin to emerge in some southern states. In this context, Sell cites several opportunities for collaboration between southern-based companies to work with northern-based corporations and business associations to develop the needed incentives (pp. 212-214).

Sell's book, with its emphasis on the power of ideas, provides a welcome offset to the tendency of much international relations analysis to ignore the role played by ideology altogether. She seems, however, to set up a false dichotomy between explanations that appeal either to materialist factors or to ideological factors without giving due consideration to those that emphasize the interaction of such forces. Interestingly, she does allow for precisely 
this last possibility in her admission that Gramscian approaches provide this sort of interaction. ${ }^{8}$ She writes that Gramscian approaches "take ideas seriously and stress the close relationship between power structures and ideas" (p. 12). She unreflectively rejects this option, however, on the grounds that Gramscian theories themselves privilege structural explanations over those that emphasize the autonomous influence of ideas. Again she opts instead for an interpretivist position that allows for a greater role played by "voluntarism and choice" (p. 13).

The problem is that this "interpretivist" perspective is ultimately unconvincing. While it is easy to show that policies of nations undergo changes over time, the chances of these policies becoming effective in the long run clearly have a great deal to do with such matters as technology, economic crises, and other conjunctural (structural) events. Sell herself seems to realize this at several points in her argument where she demonstrates the importance of structural factors in shaping the "learning" experiences of both developed and developing nations during the 1970s and 1980s. The economic crisis of the 1980s, for example, forced the developing countries to abandon their demands for a code of conduct for the regulation of transnational corporation behavior that sought to advance the development goals of the poorer countries (p. 97).

The flaw in Sell's own structural analysis is her insistence on treating nation-states as "unit-level actors." This treatment leaves the indefensible impression that nations are univocal and obscures the fact that they are composed of competing, often conflicting, classes and that classes themselves may be characterized by divisions. This failure to recognize class dynamics has important implications for Sell's analysis of the state and its policy-making apparatus. Rather than reify the state as a univocal, unit-level "learner," it makes much more historical sense to interpret it as an arena within which a (class-based) struggle for power takes place. By extension, then, it makes more sense to speak of regime change than of state learning to describe the shifts that characterize the redirections of state exercise of power and policy making. Once again Sell herself does a good job of illustrating precisely this point in her description of the conjunctural problems of external debt and economic crises that plagued many developing countries during the $1980 \mathrm{~s}$. On an ideological level, these problems had the result of replacing antidependency development policies with new ruling groups and elites who were more favorably inclined to a promarket, neoliberal vision. The latter view, not coincidentally, was the one being espoused by the International Monetary Fund and the commercial bank establishment, upon whom these countries depended for relief. If this ideological transformation could be called "unit-level learning," it is a narrow and coerced type of learning indeed. 
As noted earlier, Sell ultimately modifies her argument to admit that structural and material forces do act in concert with ideological ones. By way of conclusion she writes:

Overall, this book presented proximate causes for particular changes in intellectual property and antitrust attitudes and policies. Perhaps this analysis could be made compatible with structural and instrumentalist/rationalist theories. The explanations presented here might well fit into a broader Gramscian analysis. (emphasis added, p. 229)

I think that Sell is correct to describe her explanations as "proximate causes." This suggests that deeper, more fundamental forces are at work. I also believe that her qualified intimation that Gramscian analysis might have something significant to offer after all needs to be taken seriously. Unfortunately, she never pursues this line of investigation.

A superior job of describing the interplay between power, ideas, and intellectual property is provided by Christopher May in his book A Global Political Economy of Intellectual Property Rights (2000). In this work, May is primarily interested in examining IP from the standpoint of its ideological or philosophical justification. He begins by considering IPRs from the perspective of two well-established philosophical traditions. The first of these, associated with the seventeenth-century British philosopher John Locke, is described by May as an instrumentalist justification on the grounds that the establishment of property is "instrumental" to the ends of promoting profitable human activities (p. 25). The second tradition, associated with the eighteenth-century German philosopher Georg Hegel, is called a "self-developmental" justification insofar as property enables individuals to establish and realize their full human personalities. May also considers a pragmatic, or economic, justification for IP that is based in the utilitarian tradition. He argues that most ideological justifications of IP involve some combination of these traditional philosophical defenses of property and property right.

May recognizes that the philosophical justification of IP is necessarily conducted within a historically defined social structure. Such a structure is defined as a set of institutions and behavioral norms that are themselves the outcome of the exercise of power. May borrows from Susan Strange (1988) the useful notion of the "knowledge structure" to describe that portion of the social structure specifically concerned with defining the limits of "acceptable knowledge." The knowledge structure is one of several structures that govern the functioning of the international political economy. Others include the security, financial, and productive structures. These structures interact to produce material outcomes with definite distributional consequences. That 
is to say, the outcomes produced are in no way class-neutral. The exercise of class power determines both the content of the knowledge structure and how this and other structures condition the functioning of the international political economy. ${ }^{9}$

Strange and May's concept of the knowledge structure provides an effective means of overcoming the false dichotomy between ideological and structural forces posed by Sell. May argues that the knowledge structure interacts with other structures in a dialectical fashion to influence the course of development of the international economy over time (p. 39) and shows how this development encourages the conversion of knowledge into commodities. This conversion process he aptly terms the "new enclosure" and notes that the TRIPS agreement is its most recent and effective instrument.

Like several of the other works I have considered in this review (Matthews is the exception), May's analysis is constrained by its essentially nationalist perspective. For May, the TRIPS agreement appears as a victory for certain fractions of U.S. corporate capital, especially those firms in the pharmaceutical, entertainment, and informatics industries. This perspective, I believe, underestimates the degree to which the agreement advances the interests of a transnational capitalist class. The corporations served by the agreement, as Matthews demonstrates, are largely transnational ones which, while headquartered in particular geographical locations, seek to maximize profits on their global operations. The goal of profit maximization dominates considerations of national allegiance or identity.

May also runs into problems in his treatment of the state and the exercise of state power. In fact, he never explicitly addresses these questions but seems to operate implicitly on neorealist assumptions. This perspective and its limitations will be discussed in detail in Chapter 4 . For now, it is sufficient to point out that neorealist theories posit the state as a collective maximizing agent seeking to advance a well-defined national interest. From this perspective, the TRIPS would be understood as an agreement imposed by strong nations on weaker ones. The problem with such an interpretation, once again, is that it offers a distorted understanding of a global economic system that has broken the bounds of national production and accumulation.

I shall close this review with a few comments on a third book that looks at the question of intellectual property rights from a largely ideological perspective. In Shamans, Software, and Spleens: Law and the Construction of the Information Society (1996), James Boyle considers the issue of intellectual property largely from a legal standpoint. Unlike Carlos Correa's investigation considered earlier, however, Boyle is less interested in discussing the technical aspects of the law as it applies to an interpretation of the TRIPS than he is in understanding the ideological context within which our under- 
standing of IP has emerged. To employ May's terminology, Boyle is interested in providing a description of how the knowledge structure as it applies to IP came to be constructed; "constructed" is Bolye's characterization and is typical of much "postmodern" analysis.

At the base of this construction, says Boyle, is the image of the "romantic author." This concept refers to those individuals who are taken to be the original creators, or transformers, of knowledge and its applications and on whom property rights are conferred as an incentive or reward for their original contributions. Boyle believes, however, that the concept has been pushed too far: "I argue that this is a bad thing for reasons of both efficiency and justice; it leads us to have too many intellectual property rights, to confer them on the wrong people, and dramatically to undervalue the interests of both the sources of and the audiences for the information we commodify" (pp. $x-x i)$.

Boyle's work is dedicated to an examination of a variety of information issues that he describes as "puzzles." The legal concept of copyright is laden with contradictions concerning the reach of ownership rights. He asks, for example, why blackmail and insider trading are illegal. Such practices, after all, involve the use of information to advance a position of market advantage, just as do more acceptable forms such as copyrights. Key to Boyle's analysis of such puzzles is the distinction between the public and private spheres, which, following Karl Marx, is fundamental to an understanding of the functioning of law in the modern liberal state. In the public sphere, we are, as citizens, all equal-distinctions of class have no standing. In the private sphere, however, differences of wealth, social background, and opportunity are determinative of real outcomes for individuals and their communities. For Boyle, the public-private distinction enables the inhabitants of a modern liberal state to ideologically reconcile a sort of social cognitive dissonance. It is also on this axis of public-private distinction that many questions involving IPRs are resolved (pp. 26-27).

Applying the author-centered paradigm to IPRs, Boyle argues that the concept stands as a gateway through which one must pass to acquire IPRs. Not all innovations, however, pass easily through. A widely disproportionate share, in fact, is claimed by rich countries and far fewer by poor countries. Boyle notes:

Curare, batik, myths, and the dance "lambada" flow out of the developing countries, unprotected by a suite of intellectual property rights, while Prozac, Levis, Grisham, and the movie Lambada! flow in - protected by a suite of intellectual property laws, which in turn are backed by the threat of trade sanctions. (p. 125) 
Boyle argues that this disparity is not entirely a consequence of the operation of the IP system. However, the system operates to exacerbate the disparity owing to a centuries-old international division of labor in which poor countries specialize in providing primary products and raw materials for which the "authorial regime" assigns a value of zero in terms of IP (p. 126). Scientists are deemed to be "authors" who transform nature. Farmers, on the other hand, are seen as a part of the naturally evolving community operating on the basis of an unchanging tradition. The contributions of farmers are consequently made invisible and unlikely to command a high reward in the market, even when they can be shown to be economically productive. It is an easy leap to attribute such contributions to the public sphere, a commons whose exploitation then becomes the target of the private sphere by the authentic "author" (p. 130). The result is a system characterized by its colossal unfairness as well as its inefficiency.

In speculating about the character of and alternatives to the prevailing IP system, Boyle asks a number of useful questions.

Does this system rest on evidence or on faith? Do we want to consider a system that would have more protection for information production and less protection for the production of innovation? Do all the types of innovation that get protection actually need it? If not, is it necessary, for reasons of administration and formal realizability, to cast our net so wide? In its overall effects, does this system disproportionately help or hurt developing countries and the individual author or creator? Does this system undervalue the public domain and, if so, will it actually end up diminishing future innovation and impeding future innovators? (pp. 140-141)

Boyle makes the extremely important point that a single "Procrustean" concept of information production and ownership will not be able to satisfactorily address this list of questions for the diverse types of production in which human societies are engaged. And yet such a concept is precisely what the TRIPS agreement seeks to impose.

\section{Overview of the Chapters}

Chapter 2 provides a critical review of the traditional philosophical approaches to the concept of property right. It includes a discussion of the Lockean labor theory of property, the Hegelian personality justification, and the utilitarian justification (both in its familiar Benthamite version and its less familiar, but useful, Godwinian interpretation). The approaches inspired by Locke and Hegel are found to fail to offer compelling justifications for private property 
in ideas. The utilitarian philosophies, especially that associated with Bentham, also have difficulties. Parallels may be drawn between the applicability of these philosophic approaches to IPRs and to proposals calling for an international agreement on minimum labor standards for workers. One might well ask why there is no such agreement on trade-related international labor standards (TRILS) that would provide for workers a degree of the protection such as that offered by the TRIPS for those who claim ownership of intellectual property. The answer is that advocates for a TRILS agreement have not been able to mobilize nearly as effectively to imprint the emerging international regulatory infrastructure as have the proponents for stronger IPRs.

Chapter 3 examines the institution of intellectual property from the perspective of positivist economic science. By positivist economic science I refer to the research tradition that places primary emphasis on the formulation and tests of hypotheses drawn from abstract models of economic processes. It is well known that this is the dominant research tradition among academic and professional economists. In the examination of this literature, I do not pretend, however, to endorse the positivist approach as a preferred one. To the contrary, I tend to believe that it often results in a very selective and ideologically biased presentation of evidence. It does, however, present evidence of a type nonetheless with which critical social science should contend rather than ignore. By critical social science, including critical economics, I refer to those research traditions that challenge both the substantive assertions and the methodological premises of the dominant discourse. As opposed to the ahistorical and methodological individualism of positivist economics, critical social science has typically emphasized the importance of historical context and the central role played by groups, including classes.

In this chapter I review recent theoretical treatments of the effect of patents on various measures of economic welfare and/or important economic policy targets. The findings are generally ambiguous, though the general conclusions seem to suggest that poor nations are better off if left to their own devices in forming an optimal national IPR regime. I also review the available econometric evidence on the impact of the strength of IPR regime on certain target variables, such as exports, direct foreign investment (DFI), and the rate of economic growth. Included in this review is my own respecification and test of an empirical model presented in an often cited paper by Lee and Mansfield (1996) that purports to show the beneficial effects of strong IPRs on DFI. These results overturn Lee and Mansfield's findings. In general, the empirical evidence is shown to be too weak to support the contention that the TRIPS agreement offers adequate short- or mediumterm benefits to justify its accession by poor countries.

The central argument advanced in Chapter 4 is that a political economic 
analysis of IPRs requires corresponding theories of the state, class, and capital as they operate in the global economy. Several candidate theories from international political economy and international relations theory are available. Three in particular provide useful insights for the analytical task at hand. These are world systems theory, associated with writers such as Immanuel Wallerstein (1974), Samir Amin (1974), and Arghiri Emmanuel (1972); hegemony theory, inspired by Antonio Gramsci (1971) and developed by Giovanni Arrighi (1993), Robert Cox (1996), and Stephen Gill (1993) among others; and internationalization of capital, theorized by Christian Palloix (1977) and more recently developed by Dick Bryan (1995). For some social scientists the sort of theoretical eclecticism represented by the selective use of elements from this collection of theories may be initially offputting. I hope to convince the reader, however, that a critical eclecticism is both appropriate and even necessary to the issues at hand.

Chapter 5 applies the findings of the preceding chapter to provide an explanation for the establishment of the TRIPS agreement as part of the international institutional infrastructure governing the capitalist world system. This explanation appeals equally to the concepts of Gramscian (consensual) hegemony and direct (bilateral) coercion. Where the latter is concerned, the role of U.S. trade policy is given emphasis. In this explanation, however, the United States is represented not as an aspiring hegemonic state in the spirit of hegemonic stability theory, but as the representative of a transnational capitalist class. The limitations of other competing interpretations (Van Grasstek 1990; Ryan 1998) are discussed.

Chapter 6 is one of two case studies of the application of the TRIPS agreement to specific industrial contexts. The pharmaceutical industry is chosen because it is among the most important to discuss from the perspective of global human welfare and because of the disproportionate influence that transnational drug producers had in influencing the negotiations leading to the establishment of the agreement. The failure of the international pharmaceutical industry to address the health problems of poor countries is discussed, as is the likely (negative) consequences for the ability of poor countries to devise indigenous solutions to those problems in the face of the TRIPS. The pharmaceutical industry is also presented as a case for which the prospects for counterhegemonic organization and struggle are very good, as evidenced by the recent Doha Declaration.

The second of the two case studies, in Chapter 7, concerns the impact of a strengthened global IPR regime on biotechnology and agriculture. This case study is included because agricultural biotech has important environmental implications as well as tremendous implications for the ability of the world's impoverished to provide themselves with the basic necessities of life. The 
case makes a useful contrast to the pharmaceutical case study for at least a couple of reasons. First, ag biotech in its IPR dimensions involves not just new commodities, but also new production processes. This fact has important implications for the process of internationalization of capital discussed in other chapters. A second, and perhaps related, reason concerns the apparently reduced prospects for successful, counterhegemonic resistance to the power of transnational capital.

Conclusions and lessons for action are considered in the final chapter. This chapter provides a brief discussion of the future of the TRIPS agreement. It then concentrates on drawing general lessons from the two case studies provided in chapters 6 and 7. These lessons are of two sorts. The first set attempts to show how the cases provide support for the general political economic interpretation of the TRIPS agreement as it is set out in Chapter 5. The second set concerns the conditions and limitations of counterhegemonic action and organization. 


\section{Notes}

\section{Chapter 1}

1. By "positivist" economics I refer to the dominant analytical tradition within the discipline that emphasizes the methods of model building and hypothesis testing as the means to establish the regularities and generalizations that many consider to constitute scientific results. I comment in greater detail on the usefulness and limitations of this tradition in Chapter 3.

2. This applies most prominently to the poor countries, though it is notable that the United States is only a recent signatory to the Berne Convention.

3. The distinction between national treatment and most-favored-nation treatment is simple. National treatment means that national claimants cannot be given deference as compared to foreign claimants. Most-favored-nation treatment means that discriminatory treatment between foreign claimants is prohibited.

4. It would be possible to copyright cross-country statistics that provide an economic profile of the world, for example. In this case, the compilation may be copyrighted but not the data itself. It would not be possible to copyright the phone book, as a counterexample.

5. John Williamson is frequently given credit for coining the term "Washington consensus" (WC) and is probably the most frequently cited proponent of this view. Though not identified as such, an early exemplar of the WC is found in an article authored by Williamson (1983) in the American Economic Review in which he advocates that IMF loans to poor countries should link the goals of relaxing external liquidity constraints to solvency considerations.

6. This is an issue that will be pursued in greater detail in the concluding Chapter 8 .

7. The instrumentalist-structuralist debate on the nature of the capitalist state has been waged among radical and Marxist scholars since at least as far back as the 1970s (Milliband 1969; Poulantzas 1978). For a recent overview, see Barrow (2000). State theory in the context of global capitalism is central to the discussion of the TRIPS agreement and will be taken up in detail in Chapter 4.

8. See the collection edited by Gill (1993) for an overview of Gramscian approaches as they apply to international relations theory.

9. There would seem to be a great deal of overlap between Strange and May's concept of "knowledge structure" and the Gramscian notion of hegemony. One could, in fact, argue that the knowledge structure is the vehicle by which hegemony is established and exercised. Gramscian hegemony is taken to be consensual in that it appeals to an accepted, or correct, view of the world and how it operates, or how it should operate. At the same time, this hegemony represents a particular class perspective which is posited not as a class perspective, but as a universal one. 


\section{Chapter 2}

1. For a sample of the latter reaction, see "March Madness" and "Protest Too Much" in New Republic 222, no. 18 (May 1, 2000): 9.

2. I do not attempt a comprehensive review of the writings of all those who have had interesting insights into the nature of property. The thinkers whose theories I do consider are frequently invoked by modern scholars who have examined the historical development of private property rights. These scholars include Ryan (1984, 1987), Macpherson (1978), and Waldron (1988).

3. A utilitarian argument such as Bentham's, according to Waldron, is qualitatively distinct from a rights-based argument of any kind.

4. This seems to be precisely what has occurred in the recent case of South Africa, where popular pressure on international drug manufacturers has forced them to make their anti-AIDS medications available at far more reasonable prices than they were initially willing to sell them.

5. Hughes notes Hegel's views on the alienation of intellectual property rights. He argues that Hegel ultimately opts for a utilitarian (economic) defense of such alienation (Hughes 1988, p. 349, n. 243.)

6. It has been widely noted that much of the "seed capital" for the intellectual goods and services marketed by private corporations is derived from tax-financed, public sources. Government, through funding of its own research centers or public universities, is an important source of basic and applied science that is routinely turned over to the private sector for further development or immediate commercialization. Even when private corporations fund their own research and development departments, these activities are often the direct and indirect beneficiaries of favorable tax laws and public subsidies. For a useful discussion of the often uncomfortable relationship between academe, government, and private corporate interests over the issue of new knowledge and property, the interested reader should consult "The Common Good" (1999); Whipple (1999); and Mitchell (1999).

7. This is derived from Coase (1960).

8. Some readers will be familiar with this problem as "the tragedy of the commons" as described by Hardin (1968).

9. The expression "anticommons" is intended to evoke the antithetical notion of Garrett Hardin's famous "tragedy of the commons" (1968), which justified private property rights based on the potential for overexploitation of common property.

10. The incentive and security justifications for property have their roots in the British utilitarian philosophical tradition, which has otherwise been extremely influential in mainstream economic theory. See Ryan (1984) for discussion.

11. Students of economic history know that technology transfer to the late developing nations, including the United States and Japan, was precisely facilitated by the widespread disrespect of the early developing nations' best attempts to slow the international flow of technology. The major difference between the eighteenth and nineteenth centuries and the twentieth and twenty-first is that in the former periods technology was more often embodied in goods and physical capital, whereas in the current period it is less so. For specifics regarding America's early experience as a technological borrower, consult Rosenburg (1972).

12. A strictly Marxian view, of course, rejects the historical or moral legitimacy of privately held capital of any sort. In this view, all capital, including intellectual prop- 
erty, is the product of a social labor process and in a society of associate producers would be held in common.

13. Some of these questions are taken up in the next chapter, while others are considered by Correa (2000), and Maskus (2000), and Maskus and Konan (1994).

14. See Ryan (1998), especially his chapter 4, for details.

\section{Chapter 3}

1. The TRIPS agreement effectively replaces a United Nations institution called the World Intellectual Property Organization (WIPO), which holds a similar mandate but has lacked effective enforcement power.

2 . It is probably accurate to say the distinction is actually less recognized among economists than it is among other social scientists. This owes less to its applicability than to the ideological dominance of positivism within economics.

3. An important distinction is to be drawn between positivist social science and a derivative methodological approach referred to as logical positivism. The latter tradition is most closely associated with the Vienna Circle and more particularly with Karl Popper. Logical positivism shares many of the presumptions of positivism as regards the purposes and methods of science. It goes to the extreme position, however, of asserting that the fundamental purpose of positive science is not explanation at all. It is, rather, prediction. As such, the truth value of assumptions that are built into a testable model is immaterial. For detailed discussion, see Katouzian (1980), Hausman (1989), and the collection of articles edited by Marr and Raj (1982).

4. Cox (1986) identifies Giambattista Vico (1774/1970) as an originator of historicism and Robert Gilpin (1984) and Ralf Dahrendorf (1959) as among his modern intellectual heirs.

5. Siebeck et al. (1990) provide an overview of the early work on these issues.

6. The limitations of static economic welfare analysis are well known. The assumption of a given endowment and allocation of productive resources and incomes predetermines the positions of market supply and demand curves. These in turn dictate market-clearing prices, which, in turn, help define the division of gains between producers and consumers, and so on. Changes in these initial endowments may yield differences in the pattern of supply and demand, market-clearing prices, and, therefore, static welfare outcomes. These latter possibilities are, of course, beyond the pale of a static, problem-solving approach, but at the heart of a critical one.

7. This argument will be familiar to those acquainted with Vernon's (1966) product cycle theory.

8. Rapp and Rozek calculated their index based on data available for 116 countries for 1984.

9. Smith reports that the correlation coefficient between the $1984 \mathrm{RR}$ and 1985 GP indexes is 75 (1999, p. 158, n. 11).

10. The groups are identified in terms of per capita U.S. dollar income as high (8356 and above), upper middle (2696-8355), lower middle (675-2695), and low (1-674).

11. Though it should be noted that the sample size is somewhat reduced for the threat of imitation interaction term due to missing data.

12. The dummy is included given Mexico's proximity and advanced integration with the United States.

13. Statistical significance at the .01 and .05 levels is indicated by ** and *, respectively. 
14. Interestingly, neither Wheeler and Mody, Lee and Mansfield, nor the present analysis is able to establish a positive and statistically significant relationship between FDI and economic openness. In the Wheeler and Mody paper, in fact, a negative and significant relationship is found.

15. See Taylor (1994) for a theoretical discussion of the consequences of asymmetric protection of IPRs for trade, wages, and economic growth.

16. See Braga and Willmore (1991) for discussion of how protectionism affects the choice of firms to innovate or imitate.

17. As Levine and Renelt (1992) have noted, the empirical literature on economic growth is notorious for the lack of robustness in its results over alternative model specifications. Measures of the investment rate and human capital formation, however, seem to recur regularly as significant determinants of growth in cross-country samples.

18. The instrumental variable (IV) approach reduces the number of usable observations to seventy-nine.

19. These additional variables include the literacy rate, number of assassinations, number of revolutions and coups per year, and dummy variables to identify sub-Saharan African and Latin American countries.

20 . Adjusted $R$-square increases from .59 to .64 in the "enriched" equation.

21. The data sources for the variables are as follows: for GROWTH, 1988 World Development Indicators; for GDI, Penn World Table 5.6; for SECED, Human Development Report (United Nations 2001). The sample covers forty-three developed and less developed countries.

\section{Chapter 4}

1. Clearly there are far more than three models that might be considered. In the interest of an efficient presentation, I choose to focus on three that I believe are potentially well suited to the analytical tasks.

2. Cox, following Gramsci, at the same time points out that he explicitly rejects "historical economism" (1996, pp. 131-132).

3. It will be immediately apparent that the WST concept of hegemony concentrates on the exercise of power by states in the interstate system in a fashion more consistent with realist interpretations of international relations than with the broader and more complex Gramscian understanding of the term.

4. Shannon (1989) does a nice job of reviewing the debate between WST theorists and their critics, which has at times taken on sectarian overtones.

5. Arrighi's views will be given much further discussion below.

6. Notably, Cypher admits that the dependency approach is not entirely oblivious to the importance of production in its analysis.

7. An additional and, in my opinion, less credible criticism sometimes leveled at WST is that, as a "structuralist" theory of the world economy, it leaves little room for human agency, promoting a sort of political quiescence and, therefore, operating to undermine counterhegemonic political action. The assertion that structuralist analysis somehow negates a progressive political project is a non sequitur. It would seem, on the other hand, that effective politics requires an understanding of both constraints and opportunities that only an understanding of structure can provide. Chase-Dunn (2002) argues, for example, that WST demonstrates that the best opportunities to challenge the dominant nodes of power in the world capitalist system 
occur in the semiperiphery. It is here that development of productive forces has occurred sufficiently to create a working class with potential to challenge capitalist social relations, but without the sort of social democratic compromises that tend to mute labor militancy, as has occurred in the center countries. Whatever plausibility this particular argument may have, I believe that Chase-Dunn's general point regarding the usefulness of WST for informing counterhegemony organization and resistance is correct.

8. Stephen Hymer (1979) has written extensively on the role of the multinational corporation in promoting both the internationalization of capital and the "law of uneven development." His work, in my view, provides a good illustration of how the dependency/IOC theories offer complementary rather than competing perspectives on underdevelopment. Perhaps not coincidentally, Hymer arrived at an understanding of the exercise of state power in the global economy very close to the view I seek to advance in my own argument. Hymer's views, which are worthy of consideration in some detail, are taken up in the appendix to this chapter.

9. Tax reform in the less developed countries more often than not involved the imposition of a national value-added tax on consumption goods. Such a tax is well known to be regressive in its incidence, falling disproportionately on low-income households. Labor flexibilization is a euphemism for policies that delegitimate labor unions and grant greater latitude to employers in their hiring practices.

10. The Settlement of Westphalia established the modern system of states even as it dissolved the Holy Roman Empire. Besides resolving a variety of territorial disputes, the settlement is said to have marked the end of religious warfare and promoted a new era of religious toleration. These latter accomplishments must be understood as helping to provide a propitious climate for the expansion of capitalist accumulation.

11. This is not to suggest, of course, that military strength was no longer relevant to conceptions of national strength and security. It is rather to argue that military might was no longer the sine qua non of interstate competition among developed capitalist states. Only under such circumstances, for example, could Japan emerge as a contender for global hegemonic leadership in the late twentieth century.

12. Noting that states perform certain necessary functions in facilitation of capital accumulation is not necessarily to adopt a "functionalist" theory of the capitalist state. According to such a theory, forms of state control invariably correspond to particular requirements of capital's reproduction. Jessop (1990), for example, argues that whether or not state form follows function is problematical. He writes:

\footnotetext{
Despite the loud and frequent proclamation by some Marxist theorists that the state is simply the ideal collective capitalist, its institutional separation clearly permits a dislocation between the activities of the state and the needs of capital. Conversely, although some theorists (such as Hindess and Hirst) sometimes seem to suggest that there is a necessary non-correspondence between the state and the economic region, correspondence does seem possible but must be constituted in the course of a struggle whose outcome is always contingent (p. 206).
}

For a more complete discussion of the form-function nexus as it applies to the theory of the capitalist state, see Jessop (1982).

13. The "secondary" character of this function is not to suggest its relative unimportance as compared to the other "primary" functions, according to Bryan (1995, p. 72). It is secondary only because its historical contingency depends on the charac- 
ter of capitalist competition, whereas the primary functions are a matter of logical necessity for capitalist accumulation.

14. The hegemonic position of the United States is given further evidence by the failure of an additional proposed Bretton Woods institution, the International Trade Organization (ITO). As a precursor organization to the GATT, the ITO was an especially ambitious proposal that sought to oversee not only international trade but also international investment, commodity agreements, state trading, and international macroeconomic coordination. All of this was deemed by the United States to require too great a devolution of authority to the organization and was effectively vetoed on this basis.

15. While some scholars limit the term transition economy to refer to the former Soviet Union and Eastern European nations that began to develop market systems in the late 1980s, others have employed the term more widely to include those nations in the periphery and semiperiphery whose reform measures did not require the complete dismantling, or abandonment, of a full command system.

16. For contrasting views of the spread of neoliberal doctrine in Latin America, it is interesting to compare Petras (1992) with Hojman (1994).

17. The North American Free Trade Agreement (NAFTA) can be understood as a precursor agreement to the Uruguay Round that accomplished on a regional basis what the WTO is established to address on a global level. An interpretation of the NAFTA perfectly consistent with the perspective of IOC under U.S. hegemonic leadership adopted here is provided by Panitch (1994), who writes:

What is particularly important to stress, however, is that this is not something imposed on the Canadian and Mexican states by American capital and state as external to the latter, rather it reflects the role adopted by the Mexican and Canadian states in representing the interests of their bourgeoisies and bureaucracies as these are already penetrated by American capital and administration. (emphasis in original, p. 75)

18. Morrissey and Rai (1995) explain that the motivation for TRIMS among the less developed countries often involves a desire to offset the distortions caused by the restrictive business practices, such as transfer pricing, of the TNCs themselves. The authors note that nothing in the TRIMS agreement of GATT 1994 recognizes that such efficiency-reducing distortions may emanate from the TNCs. Moreover, the authors show that the TRIMS agreement is inadequate to its alleged task of increasing welfare.

19. Notwithstanding the GATT TRIMS agreement, the United States wasted no time demonstrating the seriousness of its resolve to combat TRIMS unilaterally when in 1996 it applied Section 301 sanctions against Australia on the basis of its use of an export subsidy program. Capling (1997) provides discussion of the political dynamics of Australian opposition to the GATT TRIMS agreement.

\section{Chapter 5}

1. TRIPS proponents cannot even draw on a well-established body of theory comparable to the Ricardian trade doctrine used for so long to support a liberal world trading system.

2. The differences between U.S. law and that of the Berne Convention may materially affect, for example, the ability of a magazine editor to alter an author's work to conform to the magazine's particular space requirements. For additional discussion, see Stalson (1987). 
3. Stalson notes that notwithstanding its official opposition to compulsory licensing of patents by foreign governments, the U.S. government has compelled patent holders to license users as a remedy to unfair competition, to promote educational goals, and as part of its Atomic Energy and Clean Air Acts (1987, p. 23).

4. For a discussion of the asymmetric functioning of the GATT in its dealings with poorer and richer countries, see Tussie (1987).

5. Ryan recognizes that the ability to lobby the USTR is only for those firms and industries that are well-heeled, noting that the legal fees run into the hundreds of thousands of dollars and an entire case may cost the soliciting industry a million dollars (1995, pp. 36-37).

6. As Ryan (1998, p. 82) points out, Guangdong province is home to a class of wealthy and politically influential entrepreneurs who would be especially vulnerable to the type of sanctions brought against them by the USTR.

7. It is perhaps the fact that the GATT was primarily an agreement among center countries with competing textile sectors that kept this line of production in such an exceptional status as regards trade liberalization. The poorer countries were literally peripheral actors in the early GATT talks and could not move to include textiles within the full orbit of trade negotiations.

8. Perhaps the most interesting aspect of the ATC negotiated during the mid1990 s is that it did not include trade from the largest textile exporter in the worldnamely, China. The agreement applies only to WTO members, and China did not accede to the organization until 2001. Before the admission of China, the ACT would have imposed a tremendous cost on Chinese textile producers (Jacobs 1995). The Uruguay Round then had the additional advantage for the historic bloc of preparing the ground for negotiating China's accession to the WTO.

9. The category of tropical products has historically been separated out from the rest of GATT- concerned agricultural discussions. Usually, however, the effects have been more rhetorical than substantive. During the Uruguay Round, tropical products were not, in fact, given serious treatment apart from the discussions surrounding agricultural issues more generally (Crome 1999).

10. Standard static welfare analysis suggests that NTBs that impose absolute limits on market access to foreign goods have greater costs to consumers and greater negative overall welfare costs than do comparably protectionist tariffs.

11. "Cairns" refers to the northern Queensland (Australia) city where a group of ministers from countries with substantial interests in agricultural exports initially met in August 1986.

\section{Chapter 6}

1. PhRMA (1996/1997) and cited in Ryan (1998, p. 30).

2. See Correa (2000) for more complete discussion of "international exhaustion" as it might be interpreted under the TRIPS.

3. As ' $t$ Hoen (2002) points out, the Doha Declaration is far from a definitive solution to the conflict between IP protection and the needs of public health protection.

4. Per capita consumption figures are given in constant 1980 prices.

5. Data are from Schweitzer (1997, p. 21), who cites an unpublished paper by Chang (1995).

6. See "Drug mergers change health landscape," American Medical News, January $31,2000$. 
7. The exercise of market power by the transnational pharmaceutical companies is not limited, of course, to the U.S. market. Challu (1995) shows that new legislation in Italy to strengthen patents is associated with a 200 percent increase in prices. The new law is also connected to a decrease in market share of Italy's national laboratories, a decrease in the number of drug inventions, and a deterioration in the country's pharmaceutical trade balance.

8. For additional data and a description of the UNDP Human Development Index, consult Human Development Report 2001 (United Nations Development Programme 2001).

9. The funding for the Malaria Genome Project comes from an independent research-funding agency called the Wellcome Trust. The Wellcome Trust describes itself as a charity, and one of its self-articulated guiding principles is that "research funded by the Trust is charitable in nature (i.e., gives adequate public benefit with only incidental private benefit) and is not constrained by commercial or other interests of the researcher. Discoveries, inventions, and other knowledge arising from Trust-funded research are made freely available to the wider scientific community." Greater detail may be found at the following Internet address: ww.wellcome.ac.uk/en/1/awt.html.

10. Indian law limited process patents to seven years.

11. The measures take into consideration differing assumptions regarding the elasticity characteristics of demand and amount to between 3 and 8 percent of the total pharmaceutical market.

12. South Africa's Medicines Law also permits compulsory licensing, although the law has never been used for this purpose. This fact did not prevent the South African Pharmaceutical Manufacturers Association and forty pharmaceutical TNCs from bringing suit against the South African government for alleged violations of the TRIPS (Bass 2002).

13. See Brennan (2001) for a more complete discussion of the legal particulars of the dispute.

14. Scherer (2000) tells of a recent U.S. Supreme Court decision that seems to provide a precedent that delegitimates the authority of the WTO to establish and enforce international patent standards. In the case, Florida Prepaid Post-secondary Education Expense Board v. College Savings Bank, a majority ruled that Congress had exceeded its authority in nullifying individual states' immunity from patent infringement suits in federal courts (in cases where states provided due process). By analogy, argues Scherer, individual nation-states may not be subject to the dictates of supranational authority, such as the WTO, under similar "life-and-death" circumstances when they provide due legal process and "reasonable compensation."

15. At a recent meeting the WTO TRIPS Council reached an agreement that relaxes the rules prohibiting countries from importing generic versions of patented drugs designed to fight life-threatening diseases such as AIDS, malaria, and tuberculosis. For further details see "Trade agreement addresses drug access for poor countries." The agreement had been heavily resisted by the United States pharmaceutical industry (Becker 2003). The U.S. ultimately accepted the agreement under the condition that additional text was included that seriously circumscribes its application and limits its effectiveness. This additional text, called the "December 16" or "Motta text," stipulates a variety of administrative rules and procedures before imports of generics may be permitted. One effect of these restrictions is to preclude the possibility of economies of scale in the production of generics for export and make them less economically viable (MSF 2003). In addition to the Motta text, the United States has 
insisted that the new agreement apply only in cases of national health emergency, thus preventing poor countries from taking steps to prevent such emergencies from occurring in the first place. If nothing else, this latest agreement and its accompanying publicity are a prime illustration of the continuing struggle for Gramscian (consensual) hegemony as it applies to the international IPR regime.

16. Quoted in Winestock and Cooper (2001).

17. This does not exclude the possibility of charitable contributions from such private philanthropic agencies as the Gates Foundation, for example. Such contributions cannot, however, be assumed to occur in the necessary amounts when they are needed. That is to say, the important work of providing health care to the world's poor majorities cannot be subject to the caprice of "soft money" budgeting.

18. See Zimmerman (2001) for a journalistic account of how pharmaceutical TNCs have prevented the transfer to poorer countries of patented vaccine technology developed under the auspices of a PPP.

\section{Chapter 7}

1. Some large TNCs such as Monsanto and Pfizer actually straddle the two industries.

2. Neither is it obvious how forthcoming the center countries will actually be in providing the promised improved access. U.S. president George W. Bush has already indicated his willingness to play the card of trade protectionism in his bid for reelection in 2004.

3. In the language of Marxian economics, this point could be made by noting that while pharmaceutical outputs tend to involve capital in its circuit of circulation, agriculture biotech implicates capital in both its circuits of production and circulation.

4. See the appendix to this chapter for a detailed listing of GMOs that are currently approved by the United States Department of Agriculture and Environmental Protection Agency for use and sale in the United States. Not all crops are currently being marketed. Some are currently being marketed under names other than those indicated in the table. Once a crop passes through the regulatory process, it may be sold under a variety of different names. Consult the Web site of the Union for Concerned Scientists at www.ucsusa.org for more detail.

5 . This is obviously another point in which the ag biotech case closely parallels the pharmaceutical case.

6. Kloppenburg ( 1988, p. $300, n$. 1) notes that, as of 1985 , patents for about 5,000 plants have been issued under the PPA - about 70 percent for ornamentals, 20 percent for fruits, and 10 percent for trees and shrubs.

7. For additional discussion of how hybridization transformed the technology and social relations of production agriculture, see Berlan and Lewontin (1986).

8 . The 1991 revision of UPOV can be understood as an attempt to update the agreement so as to make it TRIPS effective. See Lesser (2000) for discussion of the limitations of UPOV as an effective sui generis system of PBRs for TRIPS purposes.

9. Some critics have argued that a measure of the popularity of the convention for many countries owes precisely to the U.S. refusal to become a part of the agreement. For these countries, the convention is a means to assert their sovereign rights of control over their genetic resources against encroachments of foreign interests (Raustiala and Victor 1996).

10. Other contradictions noted by Cleaver include regional disparities and uneven 
development arising from the fact that HYVs and their related technologies perform differently according to the quality of land employed. Ecological contradictions arise because the use of chemical herbicides and pesticides contaminates land and water resources and has a negative impact on human health. Also, the problems of genetic erosion and uniformity are often cited as outcomes of the widespread introduction of HYVs.

11. Vavilov centers are collection of plant genetic materials gathered from the five continents in the 1920s and 1930s by the N.I. Vavilov All-Russian Scientific Research Institute of Plant Industry. The institute is named for Nikolai I. Vavilov who was its director from 1917.

12. See Table 7.1.

13. Soybeans are an important ingredient in a wide variety of processed foods as well as an important form of animal feed.

14. Jepson argues that the fact that GM innovations tend to enter the production process at particular stages, rather than to transform the entire process of agricultural production, limits the ability of transnational capital to capture and dominate the production process and thereby alter production relations. I believe this author may, however, underestimate the transforming power of ag biotech to alter the costs of production in ways that will place larger, better endowed growers in a privileged position relative to the global market. Also, the real crux of the biotech debate as it concerns Brazilian soybeans appears to turn on the marketability of the commodity in European markets. To some extent, this consideration, which is clearly external to Brazil itself, illustrates the country's continuing vulnerability as a semiperipheral country. At the same time, these facts do not invalidate Jepson's well-considered observations on the indeterminate nature of the juridical-political struggle over GM technology.

\section{Chapter 8}

1. A similar type of tax on capital account (international financial) transactions has been proposed by Schaberg (1998) as a way of reducing the instability caused by rapid movements of portfolio, "hot," capital into and out of emerging and less developed market economies. It should be clear that proposals such as these whose intent is to stabilize the operational impacts of the internationalization of capital are really far from adequate if the intention is wholesale transformation of the global regime of accumulation.

2. There remains considerable debate about the effectiveness of the Bush plan as compared to alternatives proposed by Bush's political opponents. For discussion, see Adams and Hitt (2002).

3. The Center for Food Safety (CFS) has recently organized a legal petition on behalf of Northern Plains wheat farmers and directed to the United States Department of Agriculture to impose a moratorium on the development of genetically modified wheat (GMW). Among the claims of the petitioners is the fear that GMW will contaminate non-GMW via pollination. Given the resistance of foreign markets to genetically modified crops, farmers fear the loss of markets abroad as well as negative environmental side effects. Consult the CFS Web site at www. centerforfoodsafety.org for more details. 


\section{References}

Adams, Chris, and Greg Hitt. 2002. "Bush deals blow to big drug makers." Wall Street Journal, October 22: A3.

Amin, Samir. 1974. Accumulation on a World Scale: A Critique of the Theory of Underdevelopment. New York: Monthly Review Press.

Aoki, Reiko, and Thomas J. Prusa. 1993. "International standards for intellectual property protection and R\&D incentives." Journal of International Economics 35, no. $3 / 4$ (November): 252-270.

"Argentine farms: Unhappy." 1994. Economist 332, no. 7877 (August 20): 36.

Arrighi, Giovanni. 1993. "The three hegemonies of historical capitalism." In Gramsci, Historical Materialism and International Relations, ed. Stephen Gill, 148-185. Cambridge: Cambridge University Press.

Arrow, Kenneth J. 1962. "Economic welfare and the allocation of resources for inventions." In The Rate and Direction of Inventive Activity, ed. R.R. Nelson, 609-625. Princeton, NJ: Princeton University Press.

Ballance, Robert, Janos Pogany, and Helmut Forstner. 1992. The World's Pharmaceutical Industries: An International Perspective on Innovation, Competition and Policy. London: Edward Elgar.

Barakat, Pierre. 2002. "Prescription drug prices continue to soar." Business and Economic Review 48, no. 2 (January-March): 25-26.

Barrow, Clyde W. 2000. "The Marx problem in Marxian state theory." Science and Society 64, no. 1 (Spring): 87-118.

Bass, Naomi A. 2002. "Implications of the TRIPS agreement for developing countries: Pharmaceutical patent laws in Brazil and South Africa in the 21 st century." George Washington International Law Review 34, no. 1: 191-222.

Beck, R.L. 1981. "Competition for patent monopolies." Research in Law and Economics 3: 91-110.

Becker, Elizabeth. 2003. "Poor nations can purchase cheap drugs under accord." New York Times, August 31, 2003, www.nytimes.com.

Bello, Walden. 1999. "The WTO's big losers." Far Eastern Economic Review 162, no. 25 (June): 54.

Bentham, Jeremy. 1987. The Theory of Legislation. Littleton, CO: F.B. Rothman.

Berlan, Jean-Pierre, and Richard C. Lewontin. 1986. "The political economy of hybrid corn." Monthly Review 38, no. 3 (July/August): 35-47.

Bhagwati, Jagdish N., and Hugh T. Patrick, eds. 1991. Aggressive Unilateralism: America's 301 Trade Policy and the World Trading System. Ann Arbor: University of Michigan Press. 
Bijman, W.J.J. 2001. "How biotechnology is changing the structure of the seed industry." International Journal of Biotechnology 3, nos. 1/2: 82-94.

Boisvert, Valerie, and Armelle Caron. 2002. "The Convention on Biological Diversity: An institutionalist perspective of the debates." Journal of Economic Issues 36, no. 1 (March): 151-166.

Bornschier, Volker, and Christopher Chase-Dunn. 1985. Transnational Corporations and Underdevelopment. New York: Praeger.

Bosman, Maarten, and Alwyn Mwinga. 2000. "Tropical diseases and the 10/90 gap." Lancet 356 (December): S63.

Boyle, James. 1996. Shamans, Software, and Spleens: Law and the Construction of the Information Society. Cambridge, MA: Harvard University Press.

Braga, Helson C., and Larry N. Willmore. 1991. "Technological imports and technological effort: An analysis of their determinants in Brazilian firms." Journal of Industrial Economics 39, no. 4 (June): 421-433.

Brawley, Mark R. 1998. Turning Points: Decisions Shaping the Evolution of the International Political Economy. Peterborough, Ontario: Broadview Press.

Brennan, Terrence M. 2001. "The United States and Brazil agree to disagree over Brazil's patent law." Intellectual Property and Technology Law Journal 13, no. 9 (September): 1-6.

Brush, Stephen B. 1999. "Bioprospecting the public domain." Cultural Anthropology 14, no. 4 (November): 535-555.

Bryan, Dick. 1995. The Chase Across the Globe. Boulder, CO: Westview Press.

Burstein, M.L. 1984. "Innovations and property rights: Introduction." Economic Inquiry 22, no. 4 (October): 608-633.

Capling, Ann. 1997. "Who makes trade policy? Australia and the Uruguay Round agreement on trade-related investment measures (TRIMS)." Australian Journal of International Affairs 51, no. 3 (November): 339-354.

Center for Responsive Politics. 2002. "Pharmaceutical/Health products: Long-term contribution trends," www.opensecrets.org/index.asp .

Challu, Pablo M. 1995. "Effects of the monopolistic patenting of medicine in Italy since 1978." International Journal of Technology Management 10, no. 2-3: 237-252.

Chambers, Judith, and Robert Bertram. 1998. "The U.S. position on the Consultative Group on International Agricultural Research.' In Intellectual Property Rights III, Global Genetic Resources: Access and Property Rights, ed. Steve A. Eberhart, Henry L. Shands, Wanda Collins, and Richard L. Lower, 59-67. Madison, WI: Crop Science Society of America.

Chang, R.R. 1995. "The top 100 pharmaceutical products in the United States from 1980 to 1992." UCLA Department of Health Services, unpublished paper cited in Schweitzer (1997).

Chase-Dunn, Christopher. 1981. "Interstate system and capitalist world economy: One logic or two?" In World-System Structure: Continuity and Change, ed. W. Ladd Hollist and James N. Rosenau, 30-53. Beverly Hills, CA: Sage.

2002. "Globalization from below: Toward a collectively rational and democratic global commonwealth." ANNALS, American Association for the Advancement of Science 581 (May): 48-61.

Chin, Judith C., and Gene M. Grossman. 1990. "Intellectual property rights and NorthSouth trade." In The Political Economy of International Trade: Essays in Honor of Robert E. Baldwin, ed. Ronald Jones and Anne O. Kruegar, 90-107. Cambridge, MA: Basil Blackwell. 
Cleaver, Harry M., Jr. 1972. "Contradictions of the green revolution." Monthly Review 24, no. 2 (June): 80-111.

Coase, Ronald. 1960. "The problem of social cost." Journal of Law Economics 3, no. 1 (October): $1-44$.

"The common good." 1999. New Scientist 164, no. 2210 (October 30): 3.

Cooper, Helene, Rachel Zimmerman, and Laurie McGinley. 2001. "Patents pending: AIDS epidemic traps drug firms in a vise: Treatment vs. profits." Wall Street Journal, March 2: A1.

Cooper, Richard N. 1998. "Toward a real global warming treaty." Foreign Affairs 77, no. 2 (March/April): 66-79.

Correa, Carlos M. 2000. Intellectual Property Rights, the WTO and Developing Countries. London: Zed Books.

Cox, Robert. 1986. "Social forces, states, and world orders: Beyond intemational relations theory." In Neorealism and Its Critics, ed. Robert O. Keohane, 204-254. New York: Columbia University Press.

1993. "Gramsci, hegemony and international relations: An essay in method." In Gramsci, Historical Materialism and International Relations, ed. Stephen Gill, 49-66. Cambridge: Cambridge University Press.

1996. Approaches to World Order: Cambridge: Cambridge University Press.

Croome, John. 1999. Reshaping the World Trading System. The Hague: Kluwer Law International.

Cypher, James M. 1979. "The internationalization of capital and the transformation of social formations: A critique of the monthly review school." Review of Radical Political Economics 11, no. 4 (Winter): 33-49.

Dahrendorf, Ralf. 1959. Class and Class Conflict in Industrial Society. Stanford, CA: Stanford University Press.

Dasgupta, Partha. 1987. "The economic theory of technology policy: An introduction." In Economic Policy and Technological Performance, ed. P. Dasgupta and Paul Stoneman, 7-23. Cambridge: Cambridge University Press.

Dasgupta, Partha, and Joseph Stiglitz. 1980. "Uncertainty, industrial structure and the speed of R\&D." Bell Journal of Economics 11, no. 1 (Spring): 1-28.

Deardorff, Alan V. 1992. "Welfare effects of global patent protection." Economica 59, no. 233 (February): 35-51.

Dhar, Biswajit, and C. Niranjan Rao. 1996. "Trade-relatedness of intellectual property rights." Science Communication 17, no. 3 (March): 304-325.

Diamond, Jared. 1997. Guns, Germs and Steel: The Fates of Human Societies. New York: W.W. Norton.

Dos Santos, Teotonio. 1970. "The structure of dependence." American Economic Review 60, no. 2 (May): 235-246.

"Drug mergers change health landscape." 2000. American Medical News 43, no. 4 (January 31): 4.

Edwards, Michael, and David Hulme. 1996. "Too close for comfort? The impact of official aid on non-governmental organizations." World Development 24, no. 6 (June): 961-973.

Emmanuel, Arghiri. 1972. Unequal Exchange: A Study of the Imperialism of Trade. New York: Monthly Review Press.

Enserink, Martin. 2000. "Malaria researchers wait for industry to join fight." Science 287, no. 5460 (March 17): 1956-1958.

Evans, Peter B. 1989. "Declining hegemony and assertive industrialization: US-Brazil 
conflicts in the computer industry," International Organization 43 (Spring): 207238.

FAO. 1996. "PR 96/26-Leipzig Declaration.” Food and Agricultural Organization Press Releases, www.fao.org/waicent/ois/press_ne/presseng/h22f.htm.

FAO/CGRFA. 1983. International Undertaking on Plant Genetic Resources. Twentysecond Session of the FAO Conference. Rome.

Feinberg, R.M., and D.J. Rousslang. 1990. "The economic effects of intellectual property infringements." Journal of Business 63, no. 1 (January): 79-90.

Foer, Franklin. 2000. "Protest too much." New Republic 222, no.18, May 1: 21-23.

Frank, Andre Gunder. 1969. Latin America: Underdevelopment or Revolution? New York: Monthly Review Press.

Gerster, Richard. 2000. "How WTO/TRIPS threatens the Indian pharmaceutical industry." Third World Network, www.twnside.org.sg/title/twr 120h.htm.

Gill, Stephen, ed. 1993. Gramsci, Historical Materialism and International Relations. Cambridge: Cambridge University Press.

Gilpin, Robert. 1984. "The richness of the tradition of political realism." International Organization 38, no. 2 (Spring): 287-304.

Ginarte, Juan Carlos, and Walter G. Park. 1997. "Determinants of patent rights: A cross-national study.” Research Policy 26 (May): 283-301.

Glover, Gregory J. 2002. "Testimony for the Pharmaceutical Research and Manufactures of America Before the Federal Trade Commission and Department of Justice-Antitrust Division." Washington, DC, March 19, www.phrma.org/publications/quickfacts/24.06.2002.431.cfm.

Godwin, William. 1926. An Enquiry Concerning Political Justice. New York: Alfred A. Knopf.

Gorman, Judith. 2000. "Golden fleece: Tax-paid research gives companies new drugs they sell back to us at exorbitant prices." Progressive Populist 6, no. 13 (July 15), www.populist.com/00.13.golden.fleece.html.

Goss, Peter J. 1996. "Guiding the hand that feeds: Towards socially optimal appropriability in agricultural biotechnology innovation." California Law Review 84 , no. 5 (October): $1395-1437$.

Gottlieb, Scott. 2001. "Drug companies maintain 'astounding' profits." British Medical Journal 324, no. 7345 (May 4): 1054.

Gould, David M., and William C. Gruben. 1996. "The role of intellectual property rights in economic growth." Journal of Development Economics 48, no. 2 (March): 323-350.

Gramsci, Antonio. 1971. Selections from the Prison Notebooks. New York: International Publishers.

Hall, Stephen S. 1999. “Science triumphs, market fails.” Technology Review 102, no. 1 (January/February): 78.

Hanson, David. 1997. "Argentina punished for patent piracy." Chemical and Engineering News 75, no. 4 (January 27): 10-11.

Hardin, Garrett. 1968. "The tragedy of the commons." Science 162, no. 3859, December 13: $1243-1248$.

Harris, Gardiner, and Rachel Zimmerman. 2001. "Drug makers say WTO setback will not have significant impact." Wall Street Journal, November 15: B5.

Hausman, Daniel H. 1989. "Economic methodology in a nutshell." Journal of Economic Perspectives 3, no. 2 (Spring): 115-127.

Hawtin, Geoffrey, and Timothy Reeves. 1998. "Intellectual property rights and access 
to genetic resources in the Consultative Group on International Agricultural Research." In Intellectual Property Rights III, Global Genetic Resources: Access and Property Rights, ed. Steve A. Eberhart, Henry L. Shands, Wanda Collins, and Richards L. Lower, 41-58. Madison, WI: Crop Science Society of America.

Hegel, Georg W.F. 1996. The Philosophy of Right. Trans. by S.W. Dyde. Amherst, NY: Prometheus Books.

Heller, Michael A., and Rebecca S. Eisenberg. 1998. "Can patents deter innovation? The anticommons in biomedical research." Science 280, no. 5364, May 1: 698-701.

Helpman, Elhanan. 1993. "Innovation, imitation, and intellectual property rights." Econometrica 61, no. 6 (November): 1247-1280.

Helpman, Elhanan, and Paul Krugman. 1985. Market Structure and Foreign Trade. Cambridge, MA: MIT Press.

Hoekman, Bernard M., and Michel M. Kostecki. 2001. The Political Economy of the World Trading System. New York: Oxford University Press.

Hoffman, Vivian. 1999. "Health groups say poor nations need access to generic drugs." Boston Globe, November 27: A15.

Hojman, David E. 1994. "The political economy of recent conversions to market economics in Latin America." Journal of Latin American Studies 26, pt. 1 (February): 191-219.

Hughes, Justin. 1988. "The philosophy of intellectual property." Georgetown Law Journal 77, no. 2 (December): 287-366.

Hymer, Stephen. 1979. The Multinational Corporation: A Radical Approach: Papers by Stephen Herbert Hymer, ed. Robert B. Cohen, Nadine Felton, Morley Nkosi, and Jaap van Liere. Cambridge: Cambridge University Press.

Ingco, Merlinda D. 1996. "Tariffication in the Uruguay Round: How much liberalisation?" World Economy 19, no. 4 (July): 425-446.

Jacobs, Brenda A. 1995. "Textiles and apparel trade under WTO." China Business Review 22, no. 2 (March/April): 35-36.

Jenkins, Rhys. 1987. Transnational Corporations and Uneven Development: The Internationalization of Capital. London: Methuen.

Jepson, W.E. 2002. "Globalization and Brazilian biosafety." Political Geography 21, no. 7 (September): 905-925.

Jessop, Bob. 1982. The Capitalist State. New York: New York University Press.

1990. State Theory: Putting the Capitalist State in Its Place. University Park: Pennsylvania State University Press.

Katouzian, Homa. 1980. Ideology and Method in Economics. New York: New York University Press.

Kimble, Melinda. 1998. "The U.S. position in the development of international treaties that impact genetic resources." In Intellectual Property Rights III, Global Genetic Resources: Access and Property Rights, ed. Steve A. Eberhart, Henry L. Shands, Wanda Collins, Richards L. Lower, 69-75. Madison, WI: Crop Science Society of America.

Kindleberger, Charles P. 1973. The World in Depression, 1929-1939. Berkeley: University of California Press.

_ـ 1981. "Dominance and leadership in the international economy: Exploitation, public goods and free rides." International Studies Quarterly 25, no. 2 (June): 242-254.

Klees, Steven J. 1998. "NGOs: Progressive TOOL or neoliberal force?" Current Issues in Comparative Education 1, no. 1 (November 15): 1-6. 
Kling, James. 1996. "Could transgenic supercrops one day breed superweeds?" Science 274 , no. 5285 , October: $180-181$.

Kloppenburg, Jack R. 1988. First the Seed: The Political Economy of Plant Biotechnology, 1492-2000. Cambridge: Cambridge University Press.

Krasner, Steven D. 1976. "State power and the structure of international trade." World Politics 28, no. 3 (April): 317-347.

Krugman, Paul R., ed. 1986. Strategic Trade Policy and the New International Economics. Cambridge, MA: MIT Press.

Lake, David A. 1993. "Leadership, hegemony, and the international economy: Naked emperor or tattered monarch with potential." International Studies Quarterly 37 , no. 4 (December): 459-489.

Lall, Sanyaja. 1975. "Is 'dependence' a useful concept in analyzing underdevelopment?" World Development 3, no. $11 / 12$ (November/December): 799-810.

Lee, Jeong-Yeon, and Edwin Mansfield. 1996. "Intellectual property protection and U.S. foreign direct investment." Review of Economics and Statistics 78, no. 2 (May): 181-186.

Lesser, W. 2000. "An economic approach to identifying an 'effective sui generis system' for plant variety protection under TRIPS." Agribusiness 16, no. 1 (Winter): 96-114.

Levine, Ross, and David Renelt. 1992. "A sensitivity analysis of cross-country growth regressions." American Economic Review 82, no. 4 (September): 942-963.

Locke, John. 1963. Two Treatises of Government. New York: Cambridge University Press.

Macpherson, C.B. 1964. The Political Theory of Possessive Individualism. Oxford: Oxford University Press.

$\longrightarrow$, ed. 1978. Property: Mainstream and Critical Positions. Toronto: University of Toronto Press.

Mar, Willam L., and Baldev Raj, eds. 1982. How Economists Explain: A Reader in Methodology. Lanham, MD: University Press of America.

"March madness." 2000. New Republic 222, no. 18 (May 1): 9.

Marx, Karl. 1977. Capital. Vol. 2. New York: International Publishers.

Maskus, Keith E. 1990. "Normative concerns in the international protection of intellectual property rights." World Economy 13, no. 3 (September): 387-409.

- 1999. "Regulatory standards in the WTO: Comparing intellectual property rights with competition policy, environmental protection, and core labor standards." Institute for International Economics working paper 00-1, January.

2000. Intellectual Property Rights in the Global Economy. Washington, DC: Institute for International Economics.

Maskus, Keith E., and Denise Eby Konan. 1994. "Trade-related intellectual property rights: Issues and exploratory results." In Analytical and Negotiating Issues in the Global Trading System, ed. Alan V. Deardorff and Robert M. Stern. Ann Arbor: University of Michigan Press.

Maskus, Keith E., and Mohan Penubarti. 1995. "How trade-related are intellectual property rights?" Journal of International Economics 39, no. 3-4 (November): 227-248.

Matthews, Duncan. 2002. Globalising Intellectual Property Rights: The TRIPS Agreement. London: Routledge.

May, Christopher. 2000. A Global Political Economy of Intellectual Property Rights: The New Enclosures? London: Routledge/RIPE studies in the global political economy. 
McCarthy, Michael. 2002. "US states file lawsuit against Bristol-Myers Squibb." Lancet 359, no. 9323 (June): 2092.

Milliband, Ralph. 1969. The State in Capitalist Society. London: Weidenfeld and Nicolson.

Milner, Helen. 1991. "The political economy of U.S. trade policy: A study of the Super 301 provision." In Aggressive Unilateralism, ed. Jagdish Bhagwati and Hugh T. Patrick, 163-180. Ann Arbor: University of Michigan Press.

Mitchell, K. 1999. "Scholarship means dollarship, or, money in the bank is the best tenure." Environment and Planning 31, no. 3 (March): 381-388.

Morrissey, Oliver, and Yogesh Rai. 1995. "The GATT agreement on trade related investment measures: Implications for developing countries and their relationship with transnational corporations." Journal of Development Studies 31, no. 5 (June): 702-724.

Moschini, Giancarlo, and Harvey Lapan. 1997. "Intellectual property rights and the welfare effects of agricultural R\&D." American Journal of Agricultural Economics 79, no. 4 (November): 1229-1242.

MSF (Médecins Sans Frontières). 2003. "US seeks further restrictions on generic medicines for developing countries." Press Release (August 25), www.doctorswithoutborders.org/pr/2003/08-25-2003_pf.html.

Mullin, Rick. 2002a. "Global sales keep rising." Chemical Week 164, no. 20 (May 15): 28.

. 2002b. "States sue Bristol-Myers over cancer drug patents." Chemical Week 164 , no. 24 (June 12): 13.

Nordhaus, W.D. 1969. Invention, Growth and Welfare. Cambridge, MA: MIT Press.

- 1972. "The optimum life of a patent: Reply." American Economic Review 62 , no. 3 (June): $428-431$.

Palloix, Christian. 1977. "The self-expansion of capital on a world scale." Review of Radical Political Economics 9, no. 1 (September): 1-28.

Panitch, Leo. 1994. "Globalisation and the state." In Socialist Register, 1994, ed. Ralph Milliband and Leo Panitch, 50-93. London: Merlin Press.

Paul, James A., and Katarina Wahlberg. 2002. "Global taxes for global priorities." Global Policy Forum, www.globalpolicy.org/socecon/glotax/general/ glotaxpaper.htm.

Park, Walter G., and Juan Carlos Ginarte. 1997. "Intellectual property rights and economic growth." Contemporary Economic Policy 15, no. 3 (July): 51-61.

Penn World Table, pwt.econ.upenn.edu/.

Perelman, Michael. 1998. Class Warfare in the Information Age. New York: St. Martin's Press.

Petras, James. 1992. "Retreat of the intellectuals." In Latin America in the Time of Cholera, ed. James Petras and Morris Morley, 158-169. New York: Routledge.

Pharmaceutical Research and Manufacturers of America. 1996/1997. Annual Report. Washington, DC.

- 2002. PhRMA Annual Membership Survey, www.phrma.org/publications/ publications/profile02/index.cfm.

Primo Braga, Carlos A. 1990. "Guidance from economic theory." In Strengthening Protection of Intellectual Property in Developing Countries: A Survey of the Literature, ed. Wolfgang E. Siebeck, 17-32.Washington, DC: World Bank.

Primo Braga, Carlos A., Carsten Fink, and Claudia Paz Sepulveda. 2000. Intellectual Property Rights and Economic Development. Washington, DC: World Bank. 
Poulantzas, Nicos. 1968. Political Power and Social Classes. London: New Left Books. 1978. State, Power, Socialism. London: New Left Books.

Rapp, Richard T., and Richard P. Rozek. 1990. "Benefits and costs of intellectual property protection in developing countries." Journal of World Trade 24, no. 5 (October): 75-102.

Raustiala, Kal, and David G. Victor. 1996. "The future of the Convention on Biological Diversity." Environment 38, no. 4 (May): 16-45.

Rissler, Jane, and Margaret Mellon. 1993. Perils Amidst the Promise: Ecological Risks of Transgenic Crops in a Global Market. Cambridge, MA: Union of Concerned Scientists.

Rosenberg, Tina. 2001. "Look at Brazil." New York Times Magazine, January 28: 26. Rosenburg, Nathan. 1972. Technology and American Economic Growth. White Plains, NY: M.E. Sharpe.

Rupert, Mark. 1993. "Alienation, capitalism and the inter-state system." In Gramsci, Historical Materialism and International Relations, ed. Stephen Gill, 67-92. Cambridge: Cambridge University Press.

Ryan, Alan. 1984. Property and Political Theory. Oxford: Basil Blackwell. 1987. Property. Minneapolis: University of Minnesota Press.

Ryan, Michael P. 1995. Playing by the Rules: American Trade Power and Diplomacy in the Pacific. Washington, DC: Georgetown University Press.

- 1998. Knowledge Diplomacy: Global Competition and the Politics of Intellectual Property Rights. Washington, DC: Brookings Institute.

Scalise, David G., and Daniel Nugent. 1995. "International property protections for living matter: Biotechnology, multinational conventions and the exception for agriculture." Case Western Reserve Journal of International Law 27, no. 1 (Winter): 83-99.

Schaberg, Marc. 1998. "Globalization and financial systems: Policies for the new environment." In Globalization and Progressive Economic Policy, ed. Dean Baker, Gerald Epstein, and Robert Pollin, 195-214. Cambridge: Cambridge University Press.

Scherer, F.M. 1972. "Nordhaus's theory of optimal patent life: A geometric reinterpretation." American Economic Review 62, no. 3 (June): 422-427.

. 2000. "The pharmaceutical industry and world intellectual property standards." Vanderbilt Law Review 53, no. 6 (November): 2245-2254.

Schweitzer, Stuart O. 1997. Pharmaceutical Economics and Policy. New York: Oxford University Press.

Sell, Susan K. 1998. Power and Ideas: North-South Politics of Intellectual Property and Antitrust. Albany: State University of New York Press.

Sen, Julius. 2001. Negotiating the TRIPS Agreement: India's Experience and Some Domestic Policy Issues. Jaipur: CUTS Centre for International Trade, Economics and Environment.

Shannon, Thomas R. 1989. An Introduction to the World-System Perspective. Boulder, CO: Westview Press.

Siebeck, Wolfgang E., Robert E. Evenson, William Lesser, and Carlos A. Primo Braga, eds. 1990. Strengthening Protection of Intellectual Property Rights in Developing Countries: A Survey of the Literature. World Bank Discussion Papers, no. 112, Washington, DC: World Bank.

Smith, Pamela J. 1999. "Are weak patent rights a barrier to U.S. exports?" Journal of International Economics 48, no. 1 (June): 151-177. 
Sorkin, Andrew Ross. 2000. "Behind biggest drug merger, quest for a research pipeline." New York Times, January 18: C1.

Stalson, Helena. 1987. Intellectual Property Rights and U.S. Competitiveness in Trade. Washington, DC: National Planning Association, Committee on Changing International Realities.

Stecklow, Steve, and Matt Moffett. 1999. "Soys from Brazil." Wall Street Journal, December 28: Al.

Strange, Susan. 1988. States and Markets. London: Pintar Publishers.

Subramanian, Arvind. 1991. "The international economics of intellectual property right protection: A welfare-theoretic trade policy analysis." World Development 19 , no. 8 (August): 945-956.

Taylor, M. Scott. 1994. "TRIPS, trade, and growth." International Economic Review 35, no. 2 (May): 361-381.

't Hoen, Ellen. 2002. "TRIPS, pharmaceutical patents, and access to essential medicines: A long way from Seattle to Doha." Chicago Journal of International Law 3, no. 1 (Spring): $27-46$.

Tobin, James. 1974. "The new economics, one decade older." The Eliot Janeway Lectures on Historical Economics in Honor of Joseph Schumpeter, 1972. Princeton: Princeton University Press.

"Trade agreement addresses drug access for poor countries." 2003. Nation's Health 33, no. 9 (November): 16.

Trouiller, Patrice, Piero Olliaro, Els Toreele, and James Orbinski. 2002. "Drug development for neglected diseases: A deficient market and a public-health policy failure." Lancet 359, no. 9324 (June): 2188-2194.

Tully, James. 1980. A Discourse on Property: John Locke and His Adversaries. Cambridge: Cambridge University Press.

Tussie, Diana. 1987. The Less Developed Countries and the World Trading System: A Challenge to the GATT. New York: St. Martin's Press.

United Nations. 1997. "CBD: What the Convention says." UN Chronicle 34, no. 2 : 22-23.

United Nations Development Programme. 2001. Human Development Report 2001. New York: Oxford University Press.

United Nations High Commissioner for Human Rights. 2001. "The Office of The United Nations High Commissioner for Human Rights. Access to medication in the context of pandemics such as HIV/AIDS. UNHCHR Resolution 2001/33 (April). 2002. Access to medication in the context of pandemics such as HIV/AIDS: Report of the Secretary-General. United Nations Economic and Social Council, E/CN.4/2002/52, January: 1-17.

UNAIDS. 2002a. Fact Sheet 2002: Sub-Saharan Africa. Joint United Nations Programme on HIV/AIDS, July, www.unaids.org/en/defaykt.asp.

-2002b. Report on the global HIV/AIDS epidemic July 2002. Joint United Nations Programme on HIV/AIDS, www.unaids.org/en/resources/publications/ corporate+publications/report+on+the+global+hiv_aids+epidemic $+2002+$.asp

U.S. International Trade Commission. 1988. Foreign Protection of Intellectual Property Rights and the Effect on U.S. Industry and Trade. Washington, DC: Government Printing Office.

Van Grasstek, Greg. 1990. "Trade-related intellectual property rights: United States trade policy, developing countries and the Uruguay Round." In Uruguay Round: Further Papers on Selected Issues. Geneva: UNCTAD. 
Vernon, Raymond. 1966. "International investment and international trade in the product cycle" Quarterly Journal of Economics 80, no. 2 (May): 197-207.

Vesely, Milan. 2000. "Why curing baldness is more lucrative than saving African lives." African Business 256 (July/August): 39.

Vico, Giambattista. 1774/1970. The New Science of Giambattista Vico. Trans. from the third edition by Thomas Goddard Bergin and Max Harold Fisch. Ithaca: Cornell University Press.

Wagner, J. Martin. 2000. “The WTO's interpretation of the SPS agreement has undermined the right of governments to establish appropriate levels of protection against risk." Law and Policy in International Business 31, no. 3 (Spring): 855-859.

Waldron, Jeremy. 1988. The Right to Private Property. Oxford: Oxford University Press.

Wallerstein, Immanuel. 1974. The Modern World System. Vol. 1. New York: Academic Press.

- 1984. The Politics of the World-Economy: The States, the Movements and the Civilizations. Cambridge: Cambridge University Press.

Watal, Jayashree. 2000. "Pharmaceutical patents, prices and welfare losses: Policy options for India under the WTO TRIPS agreement." World Economy 23, no. 5 (May): 733-752.

Watanabe, Chihiro, Makoto Takayama, Akira Nagamatsu, Takashi Tagami, and Charla Griffy-Brown. 2002. "Technology spillover as a complement for high-level R\&D intensity in the pharmaceutical industry." Technovation 22, no. 4 (April): 245-258.

Watson, Rory. 2001. "Oxfam accuses Pfizer of 'moral bankruptcy." British Medical Journal 323, no. 7306 (July): 186.

Wharton, Clifton R., Jr. 1969. "The green revolution: Cornucopia or Pandora's box." Foreign Affairs 47, no. 3 (April): 464-476.

Wheeler, David, and Ashoka Mody. 1992. "International investment location decisions." Journal of International Economics 33, no. 1/2 (August): 57-76

Whipple, Dan. 1999. "Seeds of controversy." Futurist 33, no. 8 (October): 10-12.

Williamson, John. 1983. "On seeking to improve IMF conditionality." American Economic Review 73, no. 2 (May): 354-358.

Winestock, Geoff, and Helene Cooper. 2001. "Activists outmaneuver drug makers at WTO-poor nations can ignore patents to meet public-health needs." Wall Street Journal, November 14: A2.

World Development Indicators. 1988. Washington, DC: World Bank.

Yaghmaian, Behzad. 1998. "Globalization and the state: The political economy of global accumulation and its emerging mode of regulation." Science and Society 62, no. 2 (Summer): 241-265.

Zimmerman, Rachel. 2001. "Some question whether drug makers play too large a role in vaccine fund." Wall Street Journal, December 3: A12. 